\title{
Biology and Pathobiology of TDP-43 and Emergent Therapeutic Strategies
}

\author{
Lin Guo and James Shorter \\ Department of Biochemistry and Biophysics, Perelman School of Medicine at the University of Pennsylvania, \\ Philadelphia, Pennsylvania 19104 \\ Correspondence: jshorter@mail.med.upenn.edu
}

Cytoplasmic TDP-43 mislocalization and aggregation is a pathological hallmark of amyotrophic lateral sclerosis and frontotemporal lobar degeneration. TDP-43 is an RNA-binding protein (RBP) with a prion-like domain (PrLD) that promotes TDP-43 misfolding. PrLDs possess compositional similarity to canonical prion domains of various yeast proteins, including Sup35. Strikingly, disease-causing TDP-43 mutations reside almost exclusively in the PrLD and can enhance TDP-43 misfolding and toxicity. Another $\sim 70$ human RBPs harbor PrLDs, including FUS, TAF15, EWSR1, hnRNPA1, and hnRNPA2, which have surfaced in the etiology of neurodegenerative diseases. Importantly, PrLDs enable RBP function and mediate phase transitions that partition functional ribonucleoprotein compartments. This PrLD activity, however, renders RBPs prone to populating deleterious oligomers or self-templating fibrils that might spread disease, and disease-linked PrLD mutations can exacerbate this risk. Several strategies have emerged to counter TDP-43 proteinopathies, including engineering enhanced protein disaggregases based on Hsp104.

$\mathrm{O}$ ne of the greatest biomedical challenges of our era lies in the daunting reality that there continues to be no effective therapies for several ineluctably fatal and increasingly common neurodegenerative disorders connected with protein misfolding, soluble toxic oligomers, and aberrant protein aggregation (Cushman et al. 2010; Eisenberg and Jucker 2012; Prusiner 2013). One of these debilitating neurodegenerative disorders, amyotrophic lateral sclerosis (ALS), is the most common adult motor neuron disease, afflicting $\sim 2$ individuals per 100,000, with typical onset between 50-60 years of age (Robberecht and Philips 2013). Upon progression, ALS is distinguished by an unrelenting devastation of upper and lower motor neurons (Robberecht and Philips 2013). This neurodegeneration leads to progressive weakness, muscular wasting, and spasticity, which culminates in paralysis, denervation of respiratory muscles, and typically death within $\sim 3-5$ years (Robberecht and Philips 2013). There are no effective therapies for ALS, although riluzole can sometimes extend survival by $\sim 2-3$ months (Bensimon et al. 1994). Riluzole efficacy is limited and is further compounded by poor central nervous system bioavailability (Jablonski et al. 2014). The lack of treatment options is unacceptable, and we are in urgent need of effective therapeutics (Zinman and Cudkowicz 2011).

Editor: Stanley B. Prusiner

Additional Perspectives on Prion Diseases available at www.perspectivesinmedicine.org

Copyright (C) 2017 Cold Spring Harbor Laboratory Press; all rights reserved; doi: 10.1101/cshperspect.a024554

Cite this article as Cold Spring Harb Perspect Med 2017;7:a024554 
A neuropathological hallmark of ALS is the accumulation of nonamyloid, ubiquitin-positive inclusions in the cytoplasm of degenerating motor neurons and glia (Gros-Louis et al. 2006; Neumann et al. 2006; Pasinelli and Brown 2006; Kwong et al. 2008). The identity of the protein found in these inclusions varies depending on the specific form of ALS. ALS is mostly a sporadic disease (sALS), but $\sim 10 \%$ of ALS cases are familial (fALS) (Rowland and Shneider 2001; Renton et al. 2014). Mutations in SOD1, the gene encoding $\mathrm{Cu} / \mathrm{Zn}$ superoxide dismutase (Gros-Louis et al. 2006; Pasinelli and Brown 2006), have been identified in $\sim 20 \%$ of fALS cases for an overall incidence of $\sim 2 \%$ (Valentine and Hart 2003). In these cases, SOD1 is found in protein inclusions in afflicted neurons (Rotunno and Bosco 2013). However, whether wild-type (WT) SOD1 misfolds and contributes to sALS remains uncertain (Rotunno and Bosco 2013). Regardless, neurons of ALS patients without SOD1 mutations contain numerous ubiquitin-positive inclusions that are SOD1 negative (Mackenzie et al. 2007), suggesting the presence of additional pathological proteins.

It is now clear that in the vast majority of sALS and fALS cases $(\sim 97 \%)$ these protein inclusions are comprised of the RNA-binding protein (RBP) TDP-43 (Arai et al. 2006; Neumann et al. 2006; Davidson et al. 2007; Seelaar et al. 2007; Tan et al. 2007; Lagier-Tourenne and Cleveland 2009; Lagier-Tourenne et al. 2010; Ling et al. 2013). Indeed, mutations in eight different genes connected to ALS, TARDP, C9ORF72, PGRN, VCP, UBQLN2, ANG, $O P T N$, and NIPA1, result in TDP-43 proteinopathy (Lee et al. 2012; Robberecht and Philips 2013; Renton et al. 2014). However, in some ALS cases, neither TDP-43 nor SOD1 aggregates, but instead another RBP, FUS, forms cytoplasmic aggregates. TDP-43 and FUS pathology are mutually exclusive (Neumann et al. 2009; Vance et al. 2009; Hewitt et al. 2010; Mackenzie et al. 2010; Seelaar et al. 2010). Thus, two ubiquitously expressed and predominantly nuclear RBPs, TDP-43 and FUS, have risen to prominence in ALS (Neumann et al. 2006; Kwiatkowski et al. 2009; Lagier-Tourenne and Cleveland 2009; Vance et al. 2009; Lagier-Tou- renne et al. 2010; Da Cruz and Cleveland 2011; Robberecht and Philips 2013). Importantly, mutations in the genes that encode TDP-43 and FUS cause $\sim 10 \%$ of fALS cases (Da Cruz and Cleveland 2011; Renton et al. 2014). TDP43 and FUS are of particular interest because they are aggregated in the cytoplasm of sALS cases (Neumann et al. 2006; Pesiridis et al. 2009; Deng et al. 2010; Hewitt et al. 2010; Rademakers et al. 2010; Fujita et al. 2011; see also Mackenzie and Neumann 2017; Nonaka and Hasegawa 2017).

It is important to note that TDP-43, FUS, and SOD1 are not the only proteins that misfold and aggregate in ALS. Depending on the precise form of the disease, in addition to TDP-43 pathology, other RBPs can also form inclusions, including TAF15, EWSR1, hnRNPA1, hnRNPA2, and hnRNPA3 (Couthouis et al. 2011, 2012; Kim et al. 2013; Mori et al. 2013b). Moreover, the most common genetic cause of ALS is a massive expansion of the GGGGCC hexanucleotide repeat in the first intron of the C9ORF72 gene (DeJesus-Hernandez et al. 2011; Renton et al. 2011, 2014). The first intron of the C9ORF72 gene contains a polymorphic hexanucleotide repeat, GGGGCC (DeJesus-Hernandez et al. 2011; Renton et al. 2011). The repeat tract length in unaffected individuals (although variable) is typically between $\sim 5$ and 10 repeats and is almost always fewer than $\sim 23$ repeats (DeJesus-Hernandez et al. 2011; Renton et al. 2011; Rohrer et al. 2015). In C9ORF72-ALS cases, the hexanucleotide repeat tract is expanded to hundreds or even thousands of repeats, which cause impairments in nucleocytoplasmic transport (Acharya et al. 2006; DeJesus-Hernandez et al. 2011; Renton et al. 2011, 2014; Fox and Tibbetts 2015; Freibaum et al. 2015; Jovicic et al. 2015; Rohrer et al. 2015; Zhang et al. 2015). Intriguingly, the pathogenic GGGGCC repeat expansion can be translated, even in the absence of an ATG start codon and even though it is located in a noncoding region of C9ORF72 (Mori et al. 2013a,c). This unconventional repeat-associated non-ATG translation (Zu et al. 2011) occurs in all sense and antisense reading frames, producing polymers of the predicted dipeptides (sense: GGG GCC = Gly-Ala; GGG CCG = 
Gly-Pro; GGC CGG = Gly-Arg; antisense: CCC $\mathrm{CGG}=$ Pro-Arg; CCC GGC = Pro-Gly; CCG GCC $=$ Pro-Ala) (Mackenzie et al. 2013; Mori et al. 2013a,c; Zu et al. 2013). Remarkably, these various dipeptide repeat proteins form cytoplasmic inclusions in neurons of ALS and frontotemporal lobar degeneration (FTLD) patients with the C9ORF72 GGGGCC repeat expansion mutation, but not in ALS cases without the C9ORF72 GGGGCC repeat expansion (Mackenzie et al. 2013; Mori et al. 2013a,c; Zu et al. 2013). Moreover, poly-GA, poly-GR, and poly$\mathrm{PR}$ are highly toxic in model systems independent of the GGGGCC repeat expansion, and poly-GR and poly-PR can directly impair nucleocytoplasmic transport (Kwon et al. 2014; May et al. 2014; Mizielinska et al. 2014; Paul and Gitler 2014; Wen et al. 2014; Jovicic et al. 2015; Tao et al. 2015; Tran et al. 2015). Thus, multiple proteins are misfolded and aggregated in ALS, and the precise set of affected proteins depends on the underlying cause of disease.

Just as other proteins can be aggregated in ALS, TDP-43 misfolds and aggregates in other neurodegenerative diseases as well. Indeed, pathology and genetics have also connected TDP43 misfolding to a subset of FTLD cases (FTLDTDP) (Arai et al. 2006; Neumann et al. 2006; Mackenzie et al. 2010; Robberecht and Philips 2013). FTLD is a devastating neurodegenerative disorder characterized by progressive loss of neurons in the frontal and temporal lobes (Irwin et al. 2015). This neurodegeneration predominantly affects behavior, social awareness, and language and is marked by a severe deterioration in functioning and typically death $\sim 8$ years after the onset of symptoms (Irwin et al. 2015). As with ALS, in FTLD-TDP, TDP-43 is mislocalized to cytoplasmic inclusions and depleted from the nucleus in afflicted neurons (Arai et al. 2006; Neumann et al. 2009; Mackenzie et al. 2010; Irwin et al. 2015). Interestingly, sometimes neurons in the prefrontal and temporal cortex are also affected in ALS ( $\sim 15 \%$ of cases), and, likewise, FTLD can present with ALS ( $\sim 15 \%$ of cases) (Robberecht and Philips 2013). Thus, ALS and FTLD appear to represent opposite ends of the clinical spectrum of a single disease (Geser et al. 2009; Robberecht and
TDP-43: Biology, Pathobiology, and Therapeutics

Philips 2013). Prominent TDP-43 cytoplasmic mislocalization and aggregation is also evident in Perry syndrome, Alexander disease, and multisystem proteinopathy (MSP), also known as inclusion-body myopathy with Paget's disease of bone and frontotemporal dementia with ALS (IBMPFD/ALS) (Weihl et al. 2008; ChenPlotkin et al. 2010; Benatar et al. 2013; Kim et al. 2013; Walker et al. 2014). Remarkably, TDP-43 pathology is a secondary feature of several other neurodegenerative disorders, including $\mathrm{Alz}$ heimer's disease (AD), Lewy body (LB) - related diseases (e.g., Parkinson's disease), and Huntington's disease (Amador-Ortiz et al. 2007; Nakashima-Yasuda et al. 2007; Schwab et al. 2008; Uryu et al. 2008; Chen-Plotkin et al. 2010; Josephs et al. 2014a, 2016). TDP-43 lesions appear to worsen several clinical and pathological parameters observed in $\mathrm{AD}$ and LB-related disorders, indicating combinatorial effects (Nakashima-Yasuda et al. 2007; Josephs et al. 2014b; Jung et al. 2014). Collectively, these advances indicate that TDP-43 misfolding likely contributes to a broad range of neurodegenerative conditions and could be an important therapeutic target. Here, we review the biology and pathobiology of TDP-43 and consider possible therapeutic strategies to mitigate TDP-43 misfolding and toxicity in disease.

\section{TDP-43 PERFORMS DIVERSE FUNCTIONS IN THE NUCLEUS AND CYTOPLASM}

TDP-43 is a 414 amino acid RBP bearing two RNA-recognition motifs (RRMs): RRM1 (amino acids 105-169) and RRM2 (amino acids 193-253) (Fig. 1A) (Buratti and Baralle 2001). TDP-43 displays specificity for UG-rich RNA and TG-rich DNA (Buratti and Baralle 2001; Polymenidou et al. 2011; Lukavsky et al. 2013; Qin et al. 2014). RRM2 contains a nuclear export sequence (NES; amino acids 239-250) (Fig. 1A) (Winton et al. 2008). The RRMs are flanked on the N-terminal side by an $\mathrm{N}$-terminal domain (NTD; amino acids 1-78) that adopts a ubiquitin-like fold and a canonical nuclear localization sequence (NLS; amino acids 82-98), and they are flanked on the C-terminal side by a low complexity prion-like domain (PrLD; amino 
L. Guo and J. Shorter

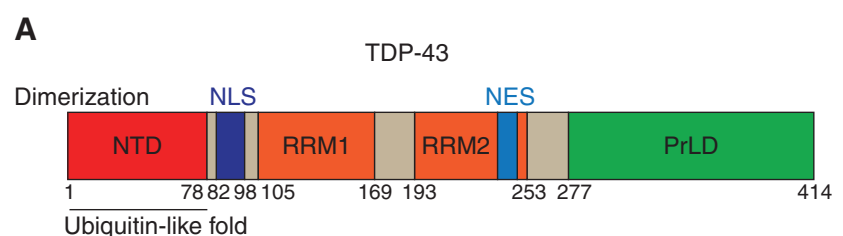

B

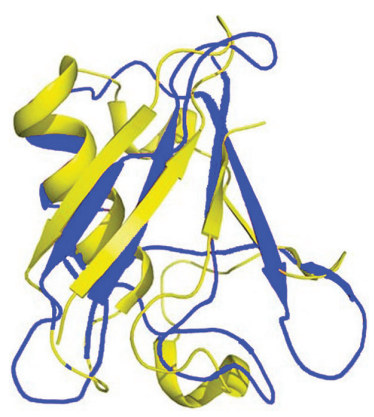

C

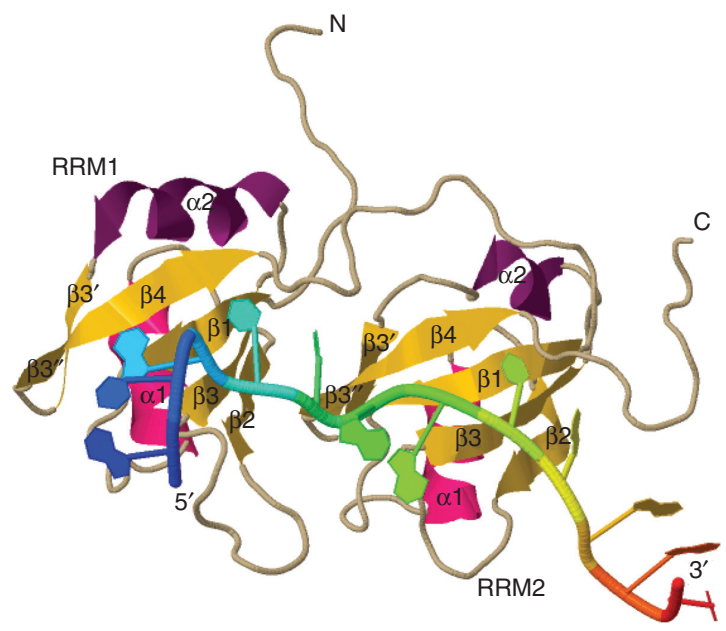

Figure 1. TDP-43 structure. (A) Domain architecture of TDP-43. Domain boundaries are numbered according to the full-length protein sequence. $(B)$ Overlay of the TDP-43 N-terminal domain (NTD) structure (blue) and ubiquitin (yellow; PDB ID code 3EHV) (Qin et al. 2014). (C) Ribbon representation of the structure of the TDP43 RNA-recognition motif (RRM) construct (amino acids 102-269) in complex with AUG12 RNA (PDB ID code 4BS2) (Lukavsky et al. 2013).

acids 277-414) (Fig. 1A) (Winton et al. 2008; Cushman et al. 2010; Fuentealba et al. 2010; Couthouis et al. 2011; King et al. 2012; Li et al. 2013; Qin et al. 2014; Mompean et al. 2016).

TDP-43 is an essential gene in mammals, zebrafish, and flies (but curiously is not essential in Caenorhabditis elegans). It is broadly expressed and, under normal conditions, resides predominantly in the nucleus but shuttles to and from the cytoplasm (Ayala et al. 2008; Winton et al. 2008; Feiguin et al. 2009; Lu et al. 2009; Chiang et al. 2010; Kraemer et al. 2010; Sephton et al. 2010; Zhang et al. 2012; Schmid et al. 2013). TDP-43 expression level is very tightly regulated (Ayala et al. 2011; Polymenidou et al. 2011). Indeed, overexpression of TDP-43 is connected with FTLD (Gitcho et al. 2009) and is detrimental in diverse model systems (Johnson et al. 2008; Ash et al. 2010; Elden et al. 2010; Tsai et al. 2010; Xu et al. 2010; Estes et al. 2011; Igaz et al. 2011; Zhang et al. 2011). TDP-43 directly regulates its own expression by binding to the $3^{\prime}$ UTR of its own mRNA and promoting its degradation (Ayala et al. 2011; Polymenidou et al. 2011; Avendano-Vazquez et al. 2012).

In the nucleus, TDP-43 performs several important functions (Ling et al. 2013). It engages promoter regions of genes and can repress transcription (Ou et al. 1995; Acharya et al. 2006; Lalmansingh et al. 2011). As well as directly binding DNA, TDP-43 physically interacts with various proteins involved in transcription (e.g., methyl-CpG-binding protein 2), although proteomic analysis suggests that TDP-43 predominantly interacts with proteins involved in splicing and translation (Freibaum et al. 2010; Sephton et al. 2011). However, the precise set of genes that are regulated at the transcriptional level by TDP-43 remains unclear. At the RNA level, TDP-43 performs diverse functions in the nucleus, which include splicing and inhibition of exon recognition, 
TDP-43: Biology, Pathobiology, and Therapeutics

long intron binding and stabilization, microRNA biogenesis, co-transcriptional limitation of double-stranded RNA formation, inhibition of specific RNA editing events, and binding long noncoding RNA (Buratti and Baralle 2001; Buratti et al. 2004; Ayala et al. 2006; Polymenidou et al. 2011; Kawahara and Mieda-Sato 2012; Lagier-Tourenne et al. 2012; Ling et al. 2013; Saldi et al. 2014; Ling et al. 2015). TDP43 also performs critical RNA-binding modalities in the cytoplasm related to RNA transport, translation, and stress-granule formation (LiuYesucevitz et al. 2010; Nishimoto et al. 2010; McDonald et al. 2011; Li et al. 2013; Ling et al. 2013; Alami et al. 2014; Coyne et al. 2014; Liu-Yesucevitz et al. 2014). These collective nuclear and cytoplasmic functions are facilitated by the RNA-binding activity of TDP-43 coupled with interactions with numerous hnRNPs (e.g., hnRNPA1 and A2), microprocessor proteins (e.g., dicer and drosha), and splicing factors (e.g., PSF, splicing factor 3a, PTBP2) (Buratti et al. 2005; D'Ambrogio et al. 2009; Freibaum et al. 2010; Ling et al. 2010; Sephton et al. 2011; Kawahara and Mieda-Sato 2012). It is estimated that TDP-43 binds to $>6000$ RNA targets in the brain, thereby impacting $\sim 30 \%$ of the transcriptome (Polymenidou et al. 2011; Tollervey et al. 2011). In the brain, TDP-43 affects the splicing of $\sim 950$ mRNAs and engages the $3^{\prime}$ UTR of $>1000$ mRNAs (Polymenidou et al. 2011; Tollervey et al. 2011). TDP-43 also engages and stabilizes very long introns in various pre-mRNAs and is estimated to affect the levels of $>600$ mRNAs in the mammalian nervous system (Polymenidou et al. 2011; Tollervey et al. 2011).

\section{TDP-43 STRUCTURE AND FUNCTION}

The structure of full-length TDP-43 remains unknown, and so precisely how TDP-43 accomplishes these diverse tasks remains uncertain as well. Nonetheless, biochemical and functional studies have yielded important insights. Several lines of evidence suggest that TDP-43 must form homodimers for optimal functionality, and dimerization appears to be mediated by the first 10 amino acids of the TDP-43 NTD
(Fig. 1A) (Johnson et al. 2009; Shiina et al. 2010; Wang et al. 2013; Zhang et al. 2013; Kuo et al. 2014; Sun et al. 2014). Further domain requirements for TDP-43 activity have been elucidated in various functional studies. For example, considerable interplay between RRM1 and RRM2 contributes to complex formation with RNA (Buratti and Baralle 2001; Lukavsky et al. 2013). Highly conserved phenylalanines in RRM1 (F147 and F149) and RRM2 (F194, F229, and F231) engage RNA directly, although RRM2 makes a weaker contribution to the overall TDP-43 RNA-binding affinity (Buratti and Baralle 2001; Lukavsky et al. 2013). In contrast, the C-terminal PrLD is not typically required for TDP-43 to bind RNA or DNA, although in isolation the TDP-43 PrLD can directly bind single-stranded DNA (Lim et al. 2016). Nonetheless, the PrLD is critical for TDP-43 activity in alternative splicing of some mRNAs and mediates protein-protein interactions with other hnRNPs, including hnRNPA1, A2, and FUS, as well as components of the dicer and drosha complexes (Ayala et al. 2005; Buratti et al. 2005; D'Ambrogio et al. 2009; Kim et al. 2010; Kawahara and Mieda-Sato 2012). However, alternative splicing of other mRNAs depends strictly on RRM1, whereas RRM2 and the PrLD are less important (Fiesel et al. 2012). Likewise, TDP-43 activity in transcriptional repression can be mediated solely by RRM1 (Lalmansingh et al. 2011), whereas TDP-43 recruitment to stress granules requires RRM1 and the PrLD (Bentmann et al. 2012). Thus, a picture is gradually emerging in which the complex multidomain architecture of TDP-43 is deployed in various ways to enable specific functions.

Structural studies of isolated TDP-43 domains have also started to yield key insights. For example, initial studies suggested that the isolated NTD (amino acids $1-78$ ) adopts a novel ubiquitin-like fold (Fig. 1B), even though the primary sequence bears little resemblance to ubiquitin (Qin et al. 2014). The significance of this putative ubiquitin-like fold in the TDP-43 NTD remains unclear, but ubiquitin-like domains in other proteins can mediate diverse functions, including direct binding to the proteasome (Madsen et al. 2007; Grabbe and Dikic 
2009). The TDP-43 NTD engages single-stranded TG-rich DNA in a sequence-specific manner, and addition of UG-rich RNA may induce aggregation of the TDP-43 NTD (Qin et al. 2014). The role of the potential ubiquitin-like fold in TDP-43 function and disease warrants further study and connects TDP-43 to another ALS disease protein, ubiquilin-2, which also harbors a ubiquitin-like domain (Hanson et al. 2010; Deng et al. 2011).

More recent studies, however, suggest that the TDP-43 NTD contains additional structural elements, including two $\beta$-strands that form a $\beta$-hairpin, which is not found in the ubiquitin fold (Mompean et al. 2016). Thus, the TDP-43 NTD may more closely resemble the C-terminal Dix domain of Axin 1 (Mompean et al. 2016). This finding suggests that the TDP-43 NTD may be more likely to bind cationic protein structures rather than nucleic acids (Mompean et al. 2016).

The structure of a TDP-43 construct comprising both RRMs (amino acids 102-269) bound to UG-rich RNA oligonucleotide, AUG12 (5'-GUGUGAAUGAAU- ${ }^{\prime}$ ), revealed that RRM1 and RRM2 adopt a canonical RRM fold $(\beta 1 \alpha 1 \beta 2 \beta 3 \alpha 2 \beta 4)$ with an additional $\beta$-hairpin $\left(\beta 3^{\prime} \beta 3^{\prime \prime}\right)$ inserted between $\alpha 2$ and $\beta 4$ (Fig. 1C) (Lukavsky et al. 2013). The $\beta$-hairpin insertion creates an expanded $\beta$-sheet surface accessible for RNA binding (Fig. 1C) (Lukavsky et al. 2013). An extended, positively charged groove on the $\beta$-sheet surface accommodates the AUG12 RNA in a single-stranded conformation in which 10 of the 12 nucleotides directly contact the protein (Lukavsky et al. 2013). Importantly, six of these $\mathrm{G}$ or $\mathrm{U}$ nucleotides are recognized sequence specifically, which explains the specificity of TDP-43 for UG-rich RNA (Lukavsky et al. 2013). The RNA is bound in a $5^{\prime}$ to 3' direction from RRM1 to RRM2 (Fig. 1C), in contrast to several other tandem RRM proteins that engage RNA in a $5^{\prime}$ to $3^{\prime}$ direction from RRM2 to RRM1 (Lukavsky et al. 2013). A central $G$ nucleotide engages both RRM1 and RRM2 and thereby stabilizes a specific tandem RRM arrangement, which enables TDP-43 to bind RNA and promote splicing activity (Lukavsky et al. 2013). Indeed, splicing repression by TDP-43 is mediated by sequence specificity for UG-rich RNA encoded by both RRMs, highaffinity RNA binding by RRM1, and exact spatial positioning of the RRMs relative to one another (Lukavsky et al. 2013).

The C-terminal, low complexity PrLD of TDP-43 (amino acids 277-414) is enriched in uncharged polar amino acids and glycine and contains two tracts (amino acids 277-293 and 346-378) that are predicted to be intrinsically unfolded (Cushman et al. 2010; King et al. 2012). The unusual amino acid composition of the PrLD resembles that of canonical prion domains of various yeast proteins, including Sup35 and Mot3 (Cushman et al. 2010; King et al. 2012; Li et al. 2013). In Sup35 and Mot3, the prion domain can switch from an intrinsically unfolded state to a prion conformation (i.e., self-templating and infectious fibrils possessing a cross- $\beta$-amyloid conformation) (Shorter and Lindquist 2005; Alberti et al. 2009; Halfmann et al. 2012). In yeast, Sup35 and Mot3 prions can be beneficial (Shorter and Lindquist 2005; Halfmann et al. 2012). Thus, by analogy, TDP-43 might also access beneficial prion or amyloid states, which might be involved in RNA-based cellular memories or epigenetic states connected to transcriptional memory (Shorter and Lindquist 2005; King et al. 2012). Here, precedent is provided by another RBP, CPEB, which forms prions via a related prion domain that may underpin longterm potentiation ( $\mathrm{Si}$ et al. 2003a,b, 2010; Shorter and Lindquist 2005; Majumdar et al. 2012; Drisaldi et al. 2015; Fioriti et al. 2015; Khan et al. 2015; Stephan et al. 2015). Likewise, another RBP with a prion domain, Rim4, forms functional amyloid-like structures that repress translation of cyclin CLB3 in meiosis I, thereby ensuring homologous chromosome segregation (Berchowitz et al. 2015; Ford and Shorter 2015). Regardless, the TDP-43 PrLD is critical for various TDP-43 functions and mediates important protein-protein interactions (Ayala et al. 2005; Buratti et al. 2005; D'Ambrogio et al. 2009; Kim et al. 2010; Kawahara and Mieda-Sato 2012). The PrLD of TDP-43 mediates phase transitions to higher-order liquid- or gel-like multimeric states that likely help organize func- 
tional and highly dynamic TDP-43 RNP granules (Johnson et al. 2009; Liu-Yesucevitz et al. 2011; Han et al. 2012; Kato et al. 2012; Wang et al. 2012; Li et al. 2013; Saini and Chauhan 2014; Guo and Shorter 2015; Lin et al. 2015; Molliex et al. 2015). Specifically, the phase transition of the PrLD of TDP-43 is mediated by an $\alpha$-helix and conserved residues in the 321-340 region (Conicella et al. 2016). Remarkably, the PrLD of TDP- 43 can be replaced with the prion domain of Sup35, yielding a TDP-43 hybrid protein that can still assemble into dynamic granules and function in alternative splicing (Wang et al. 2012). The dynamic phase-transitioning behavior mediated by the TDP-43 PrLD enables rapid assembly and disassembly of RNP granules, but is likely to simultaneously render TDP-43 prone to accessing deleterious misfolded states or pathological aggregates that contribute to disease (Hart and Gitler 2012; King et al. 2012; Buchan et al. 2013; Li et al. 2013; Ramaswami et al. 2013; Guo and Shorter 2015; Lin et al. 2015; Molliex et al. 2015).

\section{TDP-43 MISFOLDING AND PATHOGENESIS IN ALS}

TDP-43 forms pathological inclusions in degenerating neurons of ALS patients (Arai et al. 2006; Neumann et al. 2006). The inclusions are typically cytoplasmic, and, consequently, TDP43 is depleted from the nucleus (Arai et al. 2006; Neumann et al. 2006). However, nuclear TDP43 inclusions can also be observed in neurons and glia (Arai et al. 2006; Neumann et al. 2006). In ALS, TDP-43 shows abnormal phosphorylation, ubiquitylation, aberrant lysine acetylation, and accumulation of C-terminal fragments comprising the PrLD and a portion of RRM2 (Arai et al. 2006; Neumann et al. 2006; Cohen et al. 2015). More than 40 mutations in TDP-43 are now connected to sporadic and familial ALS as well as FTLD-TDP, and, remarkably, the vast majority of these mutations reside in the PrLD (Gitcho et al. 2008; Kabashi et al. 2008; Sreedharan et al. 2008; Pesiridis et al. 2009; Lattante et al. 2013). The loss of nuclear TDP-43 in degenerating neurons of ALS patients indicates that a loss of nuclear TDP-43 function likely
TDP-43: Biology, Pathobiology, and Therapeutics

contributes to disease (Lee et al. 2012; Li et al. 2013; Ling et al. 2013). Moreover, the sequestration of TDP-43 in misfolded structures in the cytoplasm also indicates a loss of cytoplasmic function as well as a toxic gain of function (Lee et al. 2012; Li et al. 2013; Ling et al. 2013). Indeed, TDP-43 clearance by autophagy induction mitigates neurodegeneration (Barmada et al. 2014; Scotter et al. 2014). In our view, it seems probable that TDP-43 pathogenesis in ALS reflects a combination of loss-of-function and gain-of-toxic function phenotypes (Lee et al. 2012; Li et al. 2013; Ling et al. 2013).

In isolation, pure TDP-43 is intrinsically aggregation prone and upon agitation rapidly assembles into pore-shaped oligomers and fibrils (Johnson et al. 2009; Couthouis et al. 2011; Fang et al. 2014). The pore-shaped TDP-43 oligomers bear remarkable ultrastructural similarity to toxic oligomers formed by other neurodegenerative disease proteins, including $\alpha$-synuclein and A $\beta$ (Lashuel et al. 2002). An oligomer-specific antibody, A11, which detects toxic oligomers formed by diverse neurodegenerative disease proteins (Kayed et al. 2003), also recognizes these pure TDP-43 oligomers (Fang et al. 2014). Moreover, purified TDP-43 oligomers are toxic to neurons in culture and also display localized neurotoxicity in vivo when injected directly into the mouse hippocampus (Fang et al. 2014). Similar TDP-43 oligomers can also be detected in the brains of transgenic TDP-43 mice and FTLD-TDP patients, but not in controls (Fang et al. 2014). These findings indicate that TDP-43 oligomers might contribute to pathogenesis.

It is likely, however, that components of the proteostasis network, including endogenous RNA substrates and interacting proteins, prevent rapid TDP-43 misfolding in vivo. Indeed, RNA ligands, including oligonucleotides from the $3^{\prime}$ UTR of the TDP-43 mRNA, prevent TDP43 aggregation in vitro and preserve TDP-43 in its native dimeric state (Huang et al. 2013; Sun et al. 2014). Accordingly, lysine acetylation events that impair RNA binding or mutation of conserved phenylalanines in the RRMs (especially RRM1) that engage RNA promote TDP-43 aggregation in cells (Elden et al. 2010; 
Wang et al. 2012; Cohen et al. 2015). However, it is critical to note that simple TDP-43 aggregation alone does not suffice to confer toxicity in multiple model systems (Johnson et al. 2008; Elden et al. 2010; Voigt et al. 2010). Thus, overexpression of RNA-binding defective TDP-43 variants leads to TDP-43 misfolding and aggregation, but not toxicity (Johnson et al. 2008; Elden et al. 2010; Voigt et al. 2010). These findings suggest that RNA binding by TDP-43 and TDP-43 misfolding are required for toxicity (Johnson et al. 2008; Elden et al. 2010; Voigt et al. 2010). Hence, interfering with either RNA binding by TDP- 43 or TDP- 43 misfolding might be sufficient to alleviate toxicity.

Why is the combination of RNA binding and protein misfolding so critical for TDP-43 toxicity? Misfolded forms of TDP-43 might sequester essential RNA molecules, RBPs, or both to promote neurodegeneration (Polymenidou et al. 2011; Tollervey et al. 2011; Armakola et al. 2012). In fact, misfolding might cause TDP-43 to bind RNA more tightly, as with Aplysia CPEB (Si et al. 2003b). RNA could stabilize or divert TDP-43 to access specific misfolded forms that are particularly neurotoxic. Indeed, different RNAs might even engender TDP-43 to fold into different misfolded forms or fibril "strains," some of which might be extremely toxic. In this regard, it is interesting to note that RNA can enable mammalian PrP to more readily access infectious conformations (Deleault et al. 2003; Wang et al. 2010, 2011a,b). Thus, perhaps certain RNAs enable TDP-43 to populate specific, deleterious self-templating conformers. Further studies at the pure protein level are necessary to test these hypotheses and to define misfolding trajectories followed by TDP-43 under different conditions.

Importantly, the TDP-43 PrLD drives TDP43 misfolding, as deletion of the PrLD prevents spontaneous TDP-43 aggregation in isolation (Johnson et al. 2009). Indeed, deletion of a short segment (amino acids 311-320) within the PrLD precludes TDP-43 aggregation in vitro (Saini and Chauhan 2011). PrLD deletion prevents aberrant TDP-43 misfolding events and toxicity in various model systems (Johnson et al. 2008; Ash et al. 2010; Wang et al. 2012).
Moreover, increased expression of C-terminal fragments of TDP-43 that harbor the PrLD confers toxicity and cytoplasmic TDP-43 aggregation in several settings (Johnson et al. 2008; Zhang et al. 2009; Ash et al. 2010; Yang et al. 2010; Pesiridis et al. 2011; Caccamo et al. 2012). Interestingly, although not required for misfolding in vitro or in yeast (Johnson et al. 2008, 2009), determinants in the TDP-43 NTD also contribute to the recruitment of full-length TDP-43 to the aggregated state and its subsequent inactivation (Budini et al. 2015; Romano et al. 2015). Moreover, under some conditions in mammalian cells, the N-terminal 10 residues of TDP-43 are important for the cytoplasmic aggregation of TDP-43 variants bearing a mutated NLS that precludes nuclear import (Zhang et al. 2013). These findings raise the possibility that TDP-43 might form a spectrum of distinct misfolded, aggregated structures, which can vary depending on the precise conditions.

Remarkably, nearly all the ALS-linked mutations in TDP-43 are located in the PrLD (Lattante et al. 2013). A yeast model of TDP-43 proteinopathy combined with pure protein biochemistry suggests that ALS-linked TDP-43 variants fall into two distinct classes (Johnson et al. 2008, 2009). The first class of ALS-linked TDP-43 mutations has no effect on TDP-43 misfolding in vitro and does not promote toxicity in yeast and includes G294A (Johnson et al. 2009). These findings suggest that some ALSlinked TDP-43 mutations in the PrLD do not impact misfolding events directly. The second class of ALS-linked TDP-43 mutations, including Q331K and M337V, accelerates spontaneous TDP-43 misfolding in isolation and potentiates TDP-43 toxicity in yeast (Johnson et al. 2009). These mutations also alter the phase-separation properties of TDP-43 (Conicella et al. 2016; Schmidt and Rohatgi 2016). Moreover, Q331K shows greater toxicity than WT TDP-43 in Drosophila (Elden et al. 2010). Indeed, similar effects of ALS-linked mutations in promoting TDP-43 misfolding and toxicity have been uncovered in diverse model systems, including pure protein settings, cell culture, flies, chicken embryos, mice, and rats (Sreedharan et al. 2008; 
Zhang et al. 2009; Barmada et al. 2010; Kabashi et al. 2010; Li et al. 2010; Ritson et al. 2010; Guo et al. 2011; Lim et al. 2016). Collectively, these findings indicate that a subset of ALS-linked TDP-43 variants likely cause disease by a gainof-toxic function mechanism (Gitler and Shorter 2011).

It is important to note, however, that loss of TDP-43 function also plays a key role in pathogenesis, as selective depletion of TDP-43 from neurons causes neurodegeneration in vivo (Feiguin et al. 2009; Wu et al. 2012; Iguchi et al. 2013). Moreover, depletion of TDP-43 from mouse embryonic stem cells causes a defect in repression of cryptic exons and cell death (Ling et al. 2015). Loss of nuclear function is anticipated from the nuclear depletion of TDP-43, as is loss of cytoplasmic function because of TDP43 sequestration in inclusions (Lee et al. 2012; Li et al. 2013; Ling et al. 2013). However, ALSlinked TDP-43 mutations can also cause loss of cytoplasmic TDP-43 function in the spatially restricted context of functional mRNP granules (Alami et al. 2014; Jovicic and Gitler 2014). TDP-43 assembles into cytoplasmic mRNP granules in neurons that show bidirectional, microtubule-dependent transport, which facilitates delivery of target mRNAs to distal neuronal compartments (Alami et al. 2014; Jovicic and Gitler 2014). The ALS-linked TDP-43 variants A315T, M337V, and G298S impair this transport activity, suggesting a partial loss of this cytoplasmic function (Alami et al. 2014; Jovicic and Gitler 2014). Thus, altered mRNP granule assembly or dynamics might contribute to neurodegeneration, and restoring functional RNP granule assembly, dynamics, or disassembly may have therapeutic utility (Li et al. 2013; Ramaswami et al. 2013).

Does TDP-43 access a bona fide prion or prion-like form? An interesting facet of ALS is the gradual spread of pathology from initiating sites to contiguous areas of the brain, which involves multiple cell types (Ravits and La Spada 2009). This pattern of disease spread has led to suggestions that a prion-like agent might be involved (Cushman et al. 2010; Polymenidou and Cleveland 2011, 2012; Udan and Baloh 2011; King et al. 2012; Grad et al. 2015;
TDP-43: Biology, Pathobiology, and Therapeutics

Maniecka and Polymenidou 2015; Josephs et al. 2016). Intriguingly, phosphorylated TDP-43 pathology in ALS has been interpreted to spread in a sequential manner with highly discernible stages that might indicate involvement of axonal pathways (Brettschneider et al. 2013, 2014; Ludolph and Brettschneider 2015).

However, does the PrLD of TDP-43 enable TDP-43 to access an infectious, self-templating amyloid form just like the prion domains of various yeast prion proteins (Shorter and Lindquist 2005)? Full-length TDP-43 purified under native conditions does not appear to readily form a classic amyloid structure recognized by diagnostic amyloid dyes such as thioflavin Tor Congo red (Johnson et al. 2009). Likewise, ALS pathology is typically devoid of amyloid structures recognized by these dyes (Neumann et al. 2007), although, in a subset of ALS cases, TDP43 skeins are recognized by thioflavin $S$ and contain TDP-43 fibrils (Robinson et al. 2013). Short, synthetic peptides derived from the PrLD of TDP-43 can access toxic amyloid conformers (Chen et al. 2010; Guo et al. 2011). However, these short peptides do not occur naturally, and so their relevance is uncertain. Moreover, the vast majority of proteins harbor short peptides able to form amyloid in isolation (Goldschmidt et al. 2010). Intriguingly, TDP43 and C-terminal TDP-43 fragments (193414) purified under denaturing conditions can form fibrils that do not bind thioflavin $\mathrm{T}$, but seed TDP-43 aggregation in vitro and in cell culture (Furukawa et al. 2011). Moreover, detergent-insoluble fractions purified from ALS brains containing TDP-43 fibrils induced aggregation of endogenous TDP-43 in neuroblastoma cells in culture (Nonaka et al. 2013). Thus, TDP-43 may indeed be able to access a prion-like conformation, which may even be transmitted across axon terminals (Feiler et al. 2015). However, convincing evidence of transmissible prion-like TDP-43 conformers will require their assembly from purely synthetic protein followed by induction of neurodegenerative disease upon injection into transgenic or WT mice, as has been achieved with $\operatorname{PrP}$ and $\alpha$-synuclein (Legname et al. 2004; Colby et al. 2009; Wang et al. 2010, 2011a,b; Luk et al. 2012). 


\section{AN RBP WITH A PrLD HAS EMERGED IN SEVERAL NEURODEGENERATIVE DISEASE SETTINGS}

In addition to TDP-43, another $\sim 70$ human RBPs harbor PrLDs of similar low complexity sequence and amino acid composition to domains that drive prionogenesis of yeast proteins like Sup35 (Cushman et al. 2010; King et al. 2012; Kim et al. 2013; March et al. 2016). These include FUS, TAF15, EWSR1, hnRNPA1, and hnRNPA2/B1, which have all surfaced as misfolded RBPs in the etiology of neurodegenerative diseases (Kwiatkowski et al. 2009; Vance et al. 2009; Cushman et al. 2010; Lagier-Tourenne et al. 2010; Couthouis et al. 2011, 2012, 2014; Neumann et al. 2011; Sun et al. 2011; King et al. 2012; Mackenzie and Neumann 2012; Kim et al. 2013; Ling et al. 2013; March et al. 2016). It is now widely thought that PrLDs enable RBP function and mediate phase transitions that partition functional ribonucleoprotein compartments (Kato et al. 2012; Li et al. 2013; Ramaswami et al. 2013). This PrLD activity, however, renders RBPs prone to populating deleterious oligomers or self-templating fibrils that might spread disease, and disease-linked PrLD mutations can exacerbate this risk (Kim et al. 2013; Ramaswami et al. 2013; Shorter and Taylor 2013). One particularly clear case involves mutations in hnRNPA1 and hnRNPA2 that underpin MSP (Kim et al. 2013; Shorter and Taylor 2013). Here, a conserved gatekeeper aspartate residue in the exact same position of the hnRNPA1 or hnRNPA2/B1 PrLD is mutated to valine (Kim et al. 2013; Shorter and Taylor 2013). Thus, the D262V mutation in hnRNPA1 or the D290V mutation in hnRNPA2 introduces a potent amyloidogenic steric zipper into the PrLD that accelerates hnRNP misfolding into self-templating fibrils and cytoplasmic-inclusion formation (Kim et al. 2013; Shorter and Taylor 2013). Remarkably, very similar mutations in the PrLD of hnRNPDL, D378N, or D378H have now been linked to limb-girdle muscular dystrophy type 1G (Vieira et al. 2014). We predict that human proteins bearing PrLDs will continue to emerge in the etiology of protein-misfolding disorders and degenerative diseases (King et al. 2012; March et al. 2016).

\section{STABILIZING NATIVE TDP-43 DIMERS AS A THERAPEUTIC STRATEGY}

In the closing sections of this review, we consider possible therapeutic approaches to combat TDP-43 proteinopathies. The only small-molecule drug treatment available for neurodegenerative disorders that targets the underlying protein-misfolding events that cause disease is Tafamidis (Bulawa et al. 2012; Nencetti et al. 2013). Tafamidis is used to treat transthyretin (TTR)-related hereditary amyloidosis (also known as familial amyloid polyneuropathy), a rare but deadly neurodegenerative disease $(\mathrm{Bu}-$ lawa et al. 2012; Nencetti et al. 2013). Tafamidis functions by stabilizing the correctly folded, native tetramer of TTR, thereby preventing TTR tetramer dissociation, which is the first and ratelimiting step of TTR amyloidogenesis (Hammarstrom et al. 2003; Hurshman et al. 2004; Bulawa et al. 2012). Based on this strong precedent, a potentially powerful therapeutic strategy might be to isolate small molecules or other agents that stabilize the native dimeric state of TDP-43 and thereby prevent misfolding (Zhang et al. 2013). Interestingly, endogenous RNA ligands may already provide this activity (Sun et al. 2014), which could be mimicked by specific aptamers.

\section{RESTORING NUCLEAR TDP-43 VIA MODULATION OF NUCLEAR TRANSPORT}

TDP-43 depletion from the nucleus is widely thought to be a critical event in pathogenesis (Lee et al. 2012; Li et al. 2013; Ling et al. 2013). One potential therapeutic strategy could be to restore nuclear TDP-43 by inhibiting TDP-43 nuclear export or stimulating TDP-43 nuclear import. Thus, small molecules that inhibit expression of nuclear export factors or increase expression of nuclear import factors could be useful. Likewise, small-molecule inhibitors of nuclear export or small-molecule enhancers of nuclear import could be advantageous. Encouragingly, orally administered reversible inhibitors of the nuclear export factor Crm1 (which decodes the TDP-43 NES) signif- 
TDP-43: Biology, Pathobiology, and Therapeutics

icantly attenuated mouse models of inflammatory demyelination and other models of axonal damage (Haines et al. 2015). Importantly, in neurons, Crm1 inhibitors prevented nuclear export of factors connected with axonal damage while retaining transcription factors in the nucleus that promote neuroprotection (Haines et al. 2015). It will be interesting to test whether these Crm1 inhibitors display efficacy against neuronal or animal models of TDP-43 proteinopathy.

\section{INHIBITING OR REDUCING EXPRESSION OF ATAXIN 2}

Genome-wide screens in yeast have uncovered a number of genetic suppressors of TDP-43 toxicity (Elden et al. 2010; Sun et al. 2011; Armakola et al. 2012). Among these, deletion suppressors are of particular interest because they could be targeted by small-molecule inhibitors or siRNA or antisense strategies. Deletion of the yeast homolog of Ataxin 2, Pbp1, suppresses TDP-43 toxicity in yeast (Elden et al. 2010). Moreover, reduced expression of Ataxin 2 in Drosophila mitigates TDP-43 toxicity (Elden et al. 2010). Polyglutamine expansions ( $>34$ Qs) in Ataxin 2 cause the neurodegenerative disease spinocerebellar ataxia type 2 (Imbert et al. 1996; Pulst et al. 1996; Lorenzetti et al. 1997). Remarkably, intermediate polyglutamine expansions (27-33 glutamines) in Ataxin 2 are a common genetic risk factor for ALS (Elden et al. 2010; Bonini and Gitler 2011; Lee et al. 2011a,b; Yu et al. 2011; Gispert et al. 2012; Hart and Gitler 2012; Hart et al. 2012). Small-molecule inhibitors of Ataxin 2 could be valuable, but the precise functions of Pbp 1 and Ataxin 2 are not completely understood, although Pbpl interacts with Pab1 and regulates mRNA polyadenylation and stress-granule biogenesis (Mangus et al. 1998). Another strategy would be to reduce Ataxin 2 expression via siRNA or antisense technology. Encouragingly, Ataxin 2 deletion in mice is not lethal and is associated with mild obesity phenotypes (Kiehl et al. 2006; Lastres-Becker et al. 2008), which augurs well for this potential approach.

\section{INHIBITING OR REDUCING EXPRESSION OF Dbr1}

The lariat-debranching enzyme, Dbr1, has also emerged as a deletion suppressor of TDP-43 and FUS toxicity in yeast (Armakola et al. 2012). Dbr1 hydrolyzes $2^{\prime}-5^{\prime}$ prime branched phosphodiester bonds, which occur at the branch point of excised lariat intron RNA, converting them to linear RNA molecules that are then degraded (Chapman and Boeke 1991). When Dbr 1 is deleted, intronic lariats accumulate and, surprisingly, co-localize with TDP-43 inclusions in the cytoplasm of yeast (Armakola et al. 2012). Thus, these accumulated intronic lariat RNAs may act as a decoy and engage TDP-43 to prevent the depletion or sequestration of essential cellular RNAs or RBPs (Armakola et al. 2012). Alternatively, lariat RNAs might engage TDP-43 and alter its misfolding pathway such that more benign TDP-43 structures accumulate. Importantly, depletion of Dbr 1 from human neuronal cells or primary rat neurons also reduced TDP-43 toxicity (Armakola et al. 2012; Sun and Cleveland 2012). Thus, the effect of reduced Dbr1 levels on TDP-43 toxicity is conserved from yeast to mammals (Armakola et al. 2012). These advances suggest that small molecules that inhibit Dbr1 activity or antisense strategies to reduce Dbr1 expression could have therapeutic utility in TDP-43 and FUS proteinopathies (Figley and Gitler 2013).

\section{TUNING EIF2 $\alpha$ PHOSPHORYLATION TO LIMIT STRESS-GRANULE ASSEMBLY}

Stress granules are cytoplasmic RNP compartments where nontranslating mRNAs, as well as factors involved in translation repression and mRNA decay, are partitioned when translation is stalled or impeded in response to environmental stress (Anderson and Kedersha 2008; Li et al. 2013; Ramaswami et al. 2013). TDP43 co-localizes with stress granules, and it has been proposed that prolonged stress-granule accumulation enables TDP-43 to access pathological conformers that cause neurodegeneration (Li et al. 2013; Ramaswami et al. 2013). Thus, agents that promote stress-granule disassembly 
or inhibit their initial assembly could have therapeutic potential ( $\mathrm{Li}$ et al. 2013; Ramaswami et al. 2013). Indeed, several genetic modifiers of TDP-43 and FUS toxicity in yeast are involved in stress-granule assembly pathways (Sun et al. 2011; Kim et al. 2014). Interestingly, phosphorylation of the translation initiation factor, eukaryotic translation initiation factor $2(\mathrm{eIF} 2 \alpha)$, decreases protein synthesis and induces stressgranule formation (Thomas et al. 2011). Inhibition of PERK ( protein kinase RNA-like endoplasmic reticulum kinase), a critical effector of unfolded protein response, by the small-molecule GSK2606414 reduces eIF2 $\alpha$ phosphorylation (Axten et al. 2012, 2013; Kim et al. 2014). Remarkably, GSK2606414 mitigates TDP-43 toxicity in Drosophila and mammalian neurons, presumably by restoring protein synthesis and thereby antagonizing stress-granule formation (Kim et al. 2014). Moreover, orally administered GSK2606414 is profoundly neuroprotective and prevents clinical disease in prion-infected mice, as do other strategies to reduce eIF $2 \alpha$ phosphorylation (Moreno et al. 2012, 2013). Unfortunately, however, GSK2606414 also causes weight loss and mild hyperglycemia, which is likely a result of an inhibition of PERK that is too severe in the pancreas (Harding et al. 2001; Moreno et al. 2013). Thus, alternative strategies to pharmacologically modulate translational inhibition caused by phosphorylated eIF $2 \alpha$ could be opportune. Interestingly, the small molecule $N, N^{\prime}$ trans-(cyclohexane-1,4-diyl)-bis-(2-(4-chlorophenoxy)acetamide (ISRIB) prevents translational inhibition downstream from eIF $2 \alpha$ phosphorylation (Sidrauski et al. 2013). Remarkably, ISRIB conferred neuroprotection in prion-diseased mice without pancreatic toxicity (Halliday et al. 2015). Moreover, ISRIB induces the rapid dissolution of preformed stress granules, thereby releasing sequestered mRNAs for translation (Sidrauski et al. 2015). It will be of great interest to determine whether ISRIB also counters TDP-43 toxicity. Finally, tuning eIF $2 \alpha$ phosphorylation to cytoprotective rather than cytotoxic levels via inhibition of specific regulatory subunits of protein phosphatases (e.g., using guanabenz and Sephin1) has also yielded promising results in restoring protein homeo- stasis and preventing neurodegeneration (Tsaytler et al. 2011; Vaccaro et al. 2013; Das et al. 2015), and should be explored further in TDP43 proteinopathy models.

\section{ENGINEERED PROTEIN DISAGGREGASES TO REACTIVATE MISFOLDED TDP-43}

Another promising therapeutic strategy is to uncover agents that reverse TDP-43 misfolding and restore TDP-43 to native structure and function (Shorter 2008, 2016; Jackrel and Shorter 2015). Such agents would contemporaneously eliminate any deleterious loss of function or toxic gain of function caused by misfolded TDP-43 (Jackrel and Shorter 2015). Moreover, any self-templating TDP-43 conformers that might spread pathology and any intrinsically toxic oligomeric forms of TDP-43 would also be cleared (Jackrel and Shorter 2015). We have engineered potentiated variants of Hsp104, an $\mathrm{AAA}^{+}$ATPase and protein disaggregase from yeast, by introducing single missense mutations into the autoinhibitory middle domain (Jackrel and Shorter 2015). These potentiated Hsp104 variants solubilize preformed TDP-43 fibrils in vitro and suppress toxicity of TDP-43 and ALS-linked variants in yeast (Jackrel and Shorter 2014a,b, 2015; Jackrel et al. 2014a,b; Sweeny et al. 2015; Torrente et al. 2016). Remarkably, potentiated Hsp104 variants also eliminate TDP-43 inclusions and restore nuclear TDP-43 localization in yeast, phenotypes that could be transformative if they were achieved in ALS patients (Jackrel and Shorter 2014a, 2015; Jackrel et al. 2014a). The challenge ahead is to apply engineered Hsp104 variants to neuronal and animal models of TDP-43 proteinopathies (Jackrel and Shorter 2015).

Hsp104 is absent in metazoa (Shorter 2008; Erives and Fassler 2015). Thus, it is also imperative to uncover human protein disaggregases that might also reverse TDP-43 aggregation and restore TDP-43 to the nucleus. Here, two systems are of particular interest. First, Hsp110, Hsp70, Hsp40, and the small heat shock proteins collaborate to dissolve and reactivate proteins trapped in disordered aggregates (Shorter 
2011; Duennwald et al. 2012; Rampelt et al. 2012; Mattoo et al. 2013; Torrente and Shorter 2013; Nillegoda et al. 2015). Hsp110, Hsp70, and Hsp40 can also depolymerize preformed amyloid fibrils (Duennwald et al. 2012; Gao et al. 2015). Moreover, Hsp110, Hsp70, and Hsp40 are important for the resolution of stress granules after stress (Cherkasov et al. 2013; Kroschwald et al. 2015; Walters et al. 2015; Jain et al. 2016). Second, the highly conserved $\mathrm{AAA}^{+}$ATPase, VCP, not only can drive clearance of stress granules via autophagy but also can potentially release soluble proteins in the process (Buchan et al. 2013; Ramaswami et al. 2013). Intriguingly, VCP mutations are a cause of ALS (Johnson et al. 2010; Shaw 2010), and ALS-linked VCP variants show defects in stressgranule clearance and perturb TDP-43 proteostasis (Ritson et al. 2010; Buchan et al. 2013; Ramaswami et al. 2013). It will be important to determine whether the Hsp110 system or the VCP system can counter TDP-43 aggregation and toxicity. Moreover, based on earlier studies on Hsp104 (Jackrel and Shorter 2015), it might also be possible to engineer the Hsp1 10 or VCP system to more effectively reverse TDP43 misfolding. Finally, it will also be of great interest to uncover small-molecule activators that enhance the disaggregase activity of the Hsp110 system or the stress-granule clearance activity of VCP (Shorter 2016). In this way, we may directly reverse the TDP-43 misfolding events that underpin diverse neurodegenerative disorders.

\section{OUTLOOK}

Although there continue to be no effective therapeutics for ALS or other TDP-43 proteinopathies, it is clear that the past several years have yielded a transformative change in our understanding of these diseases and their underlying mechanisms. To develop innovative therapies and uncover novel targets, we need to more fully understand the complexity of TDP-43's structure, function, biology, misfolding, and pathogenesis. This endeavor will require a major focused effort in basic research before translation to the clinic. Moreover, we suggest that thera-
TDP-43: Biology, Pathobiology, and Therapeutics

pies able to combine some of the approaches outlined above could yield synergistic advances similar to combination therapies that have been successfully deployed to restore proteostasis, eliminate yeast prions, and combat cystic fibrosis and HIV (Clavel and Hance 2004; Mu et al. 2008; Roberts et al. 2009; Duennwald and Shorter 2010; Shorter 2010; Wainwright et al. 2015).

\section{ACKNOWLEDGMENTS}

We thank Alice Ford for helpful comments on the manuscript. We are very grateful for support from a Glenn/AFAR Postdoctoral Fellowship for Translational Research on Aging grant from the Lawrence Ellison Foundation (L.G.), National Institutes of Health grants R21NS067354 and R01GM099836, a Muscular Dystrophy Association Research Award (MDA277268), an ALSA Investigator Initiated Award, the Life Extension Foundation, a Linda Pechenik Montague Research Award, the Packard Center for ALS Research at Johns Hopkins University, and Target ALS (J.S.).

\section{REFERENCES}

${ }^{*}$ Reference is also in this collection.

Acharya KK, Govind CK, Shore AN, Stoler MH, Reddi PP. 2006. cis-Requirement for the maintenance of round spermatid-specific transcription. Dev Biol 295: 781-790.

Alami NH, Smith RB, Carrasco MA, Williams LA, Winborn CS, Han SS, Kiskinis E, Winborn B, Freibaum BD, Kanagaraj A, et al. 2014. Axonal transport of TDP-43 mRNA granules is impaired by ALS-causing mutations. Neuron 81: 536-543.

Alberti S, Halfmann R, King O, Kapila A, Lindquist S. 2009. A systematic survey identifies prions and illuminates sequence features of prionogenic proteins. Cell 137: 146158.

Amador-Ortiz C, Lin WL, Ahmed Z, Personett D, Davies P, Duara R, Graff-Radford NR, Hutton ML, Dickson DW. 2007. TDP-43 immunoreactivity in hippocampal sclerosis and Alzheimer's disease. Ann Neurol 61: 435-445.

Anderson P, Kedersha N. 2008. Stress granules: The Tao of RNA triage. Trends Biochem Sci 33: 141-150.

Arai T, Hasegawa M, Akiyama H, Ikeda K, Nonaka T, Mori H, Mann D, Tsuchiya K, Yoshida M, Hashizume Y, et al. 2006. TDP-43 is a component of ubiquitin-positive taunegative inclusions in frontotemporal lobar degeneration and amyotrophic lateral sclerosis. Biochem Biophys Res Commun 351: 602-611. 
Armakola M, Higgins MJ, Figley MD, Barmada SJ, Scarborough EA, Diaz Z, Fang X, Shorter J, Krogan NJ, Finkbeiner S, et al. 2012. Inhibition of RNA lariat debranching enzyme suppresses TDP-43 toxicity in ALS disease models. Nat Genet 44: 1302-1309.

Ash PE, Zhang YJ, Roberts CM, Saldi T, Hutter H, Buratti E, Petrucelli L, Link CD. 2010. Neurotoxic effects of TDP-43 overexpression in C. elegans. Hum Mol Genet 19: $3206-$ 3218.

Avendano-Vazquez SE, Dhir A, Bembich S, Buratti E, Proudfoot N, Baralle FE. 2012. Autoregulation of TDP43 mRNA levels involves interplay between transcription, splicing, and alternative polyA site selection. Genes Dev 26: $1679-1684$.

Axten JM, Medina JR, Feng Y, Shu A, Romeril SP, Grant SW, Li WH, Heerding DA, Minthorn E, Mencken T, et al. 2012. Discovery of 7-methyl-5-(1-\{[3-(trifluoromethyl)phenyl]acetyl $\}$-2,3-dihydro-1H-indol-5-yl)-7Hpyrrolo[2,3-d]pyrimidin-4-amine (GSK2606414), a potent and selective first-in-class inhibitor of protein kinase $\mathrm{R}$ (PKR)-like endoplasmic reticulum kinase (PERK). J Med Chem 55: 7193-7207.

Axten JM, Romeril SP, Shu A, Ralph J, Medina JR, Feng Y, Li WH, Grant SW, Heerding DA, Minthorn E, et al. 2013. Discovery of GSK2656157: An optimized PERK inhibitor selected for preclinical development. ACS Med Chem Lett 4: 964-968.

Ayala YM, Pantano S, D’Ambrogio A, Buratti E, Brindisi A, Marchetti C, Romano M, Baralle FE. 2005. Human, Drosophila, and C. elegans TDP43: Nucleic acid binding properties and splicing regulatory function. J Mol Biol 348: 575-588.

Ayala YM, Pagani F, Baralle FE. 2006. TDP43 depletion rescues aberrant CFTR exon 9 skipping. FEBS Lett 580: 1339-1344.

Ayala YM, Zago P, D’Ambrogio A, Xu YF, Petrucelli L, Buratti E, Baralle FE. 2008. Structural determinants of the cellular localization and shuttling of TDP-43. J Cell Sci 121: $3778-3785$.

Ayala YM, De Conti L, Avendano-Vazquez SE, Dhir A, Romano M, D’Ambrogio A, Tollervey J, Ule J, Baralle M, Buratti E, et al. 2011. TDP-43 regulates its mRNA levels through a negative feedback loop. EMBO J 30: 277-288.

Barmada SJ, Skibinski G, Korb E, Rao EJ, Wu JY, Finkbeiner S. 2010. Cytoplasmic mislocalization of TDP-43 is toxic to neurons and enhanced by a mutation associated with familial amyotrophic lateral sclerosis. J Neurosci 30: 639-649.

Barmada SJ, Serio A, Arjun A, Bilican B, Daub A, Ando DM, Tsvetkov A, Pleiss M, Li X, Peisach D, et al. 2014. Autophagy induction enhances TDP43 turnover and survival in neuronal ALS models. Nat Chem Biol 10: 677-685.

Benatar M, Wuu J, Fernandez C, Weihl CC, Katzen H, Steele J, Oskarsson B, Taylor JP. 2013. Motor neuron involvement in multisystem proteinopathy: Implications for ALS. Neurology 80: 1874-1880.

Bensimon G, Lacomblez L, Meininger V. 1994. A controlled trial of riluzole in amyotrophic lateral sclerosis. ALS/Riluzole Study Group. N Engl J Med 330: 585-591.

Bentmann E, Neumann M, Tahirovic S, Rodde R, Dormann D, Haass C. 2012. Requirements for stress granule recruitment of fused in sarcoma (FUS) and TAR DNA-binding protein of $43 \mathrm{kDa}$ (TDP-43). J Biol Chem 287: 2307923094.

Berchowitz LE, Kabachinski G, Walker MR, Carlile TM, Gilbert WV, Schwartz TU, Amon A. 2015. Regulated formation of an amyloid-like translational repressor governs gametogenesis. Cell 163: 406-418.

Bonini NM, Gitler AD. 2011. Model organisms reveal insight into human neurodegenerative disease: Ataxin-2 intermediate-length polyglutamine expansions are a risk factor for ALS. J Mol Neurosci 45: 676-683.

Brettschneider J, Del Tredici K, Toledo JB, Robinson JL, Irwin DJ, Grossman M, Suh E, Van Deerlin VM, Wood EM, Baek Y, et al. 2013. Stages of pTDP-43 pathology in amyotrophic lateral sclerosis. Ann Neurol 74: 20-38.

Brettschneider J, Arai K, Del Tredici K, Toledo JB, Robinson JL, Lee EB, Kuwabara S, Shibuya K, Irwin DJ, Fang L, et al. 2014. TDP-43 pathology and neuronal loss in amyotrophic lateral sclerosis spinal cord. Acta Neuropathol 128: 423-437.

Buchan JR, Kolaitis RM, Taylor JP, Parker R. 2013. Eukaryotic stress granules are cleared by autophagy and Cdc48/ VCP function. Cell 153: 1461-1474.

Budini M, Romano V, Quadri Z, Buratti E, Baralle FE. 2015. TDP-43 loss of cellular function through aggregation requires additional structural determinants beyond its C-terminal Q/N prion-like domain. Hum Mol Genet 24: 9-20.

Bulawa CE, Connelly S, Devit M, Wang L, Weigel C, Fleming JA, Packman J, Powers ET, Wiseman RL, Foss TR, et al. 2012. Tafamidis, a potent and selective transthyretin kinetic stabilizer that inhibits the amyloid cascade. Proc Natl Acad Sci 109: 9629-9634.

Buratti E, Baralle FE. 2001. Characterization and functional implications of the RNA binding properties of nuclear factor TDP-43, a novel splicing regulator of CFTR exon 9. J Biol Chem 276: 36337-36343.

Buratti E, Brindisi A, Pagani F, Baralle FE. 2004. Nuclear factor TDP-43 binds to the polymorphic TG repeats in CFTR intron 8 and causes skipping of exon 9: A functional link with disease penetrance. Am J Hum Genet 74: 1322-1325.

Buratti E, Brindisi A, Giombi M, Tisminetzky S, Ayala YM, Baralle FE. 2005. TDP-43 binds heterogeneous nuclear ribonucleoprotein A/B through its C-terminal tail: An important region for the inhibition of cystic fibrosis transmembrane conductance regulator exon 9 splicing. J Biol Chem 280: 37572-37584.

Caccamo A, Majumder S, Oddo S. 2012. Cognitive decline typical of frontotemporal lobar degeneration in transgenic mice expressing the $25-\mathrm{kDa}$ C-terminal fragment of TDP-43. Am J Pathol 180: 293-302.

Chapman KB, Boeke JD. 1991. Isolation and characterization of the gene encoding yeast debranching enzyme. Cell 65: $483-492$.

Chen AK, Lin RY, Hsieh EZ, Tu PH, Chen RP, Liao TY, Chen W, Wang CH, Huang JJ. 2010. Induction of amyloid fibrils by the C-terminal fragments of TDP-43 in amyotrophic lateral sclerosis. J Am Chem Soc 132: 1186-1187.

Chen-Plotkin AS, Lee VM, Trojanowski JQ. 2010. TAR DNA-binding protein 43 in neurodegenerative disease. Nat Rev Neurol 6: 211-220. 
Cherkasov V, Hofmann S, Druffel-Augustin S, Mogk A, Tyedmers J, Stoecklin G, Bukau B. 2013. Coordination of translational control and protein homeostasis during severe heat stress. Curr Biol 23: 2452-2462.

Chiang PM, Ling J, Jeong YH, Price DL, Aja SM, Wong PC. 2010. Deletion of TDP-43 down-regulates Tbcld1, a gene linked to obesity, and alters body fat metabolism. Proc Natl Acad Sci 107: 16320-16324.

Clavel F, Hance AJ. 2004. HIV drug resistance. N Engl J Med 350: 1023-1035.

Cohen TJ, Hwang AW, Restrepo CR, Yuan CX, Trojanowski JQ, Lee VM. 2015. An acetylation switch controls TDP-43 function and aggregation propensity. Nat Commun 6: 5845 .

Colby DW, Giles K, Legname G, Wille H, Baskakov IV, DeArmond SJ, Prusiner SB. 2009. Design and construction of diverse mammalian prion strains. Proc Natl Acad Sci 106: 20417-20422.

Conicella AE, Zerze GH, Mittal J, Fawzi NL. 2016. ALS mutations disrupt phase separation mediated by $\alpha$-helical structure in the TDP-43 low-complexity C-terminal domain. Structure 24: 1537-1549.

Couthouis J, Hart MP, Shorter J, DeJesus-Hernandez M, Erion R, Oristano R, Liu AX, Ramos D, Jethava N, Hosangadi D, et al. 2011. A yeast functional screen predicts new candidate ALS disease genes. Proc Natl Acad Sci 108: 20881-20890.

Couthouis J, Hart MP, Erion R, King OD, Diaz Z, Nakaya T, Ibrahim F, Kim HJ, Mojsilovic-Petrovic J, Panossian S, et al. 2012. Evaluating the role of the FUS/TLS-related gene EWSR1 in amyotrophic lateral sclerosis. Hum Mol Genet 21: 2899-2911.

Couthouis J, Raphael AR, Daneshjou R, Gitler AD. 2014. Targeted exon capture and sequencing in sporadic amyotrophic lateral sclerosis. PLoS Genet 10: e1004704.

Coyne AN, Siddegowda BB, Estes PS, Johannesmeyer J, Kovalik T, Daniel SG, Pearson A, Bowser R, Zarnescu DC. 2014. Futsch/MAP1B mRNA is a translational target of TDP-43 and is neuroprotective in a Drosophila model of amyotrophic lateral sclerosis. J Neurosci 34: $15962-$ 15974.

Cushman M, Johnson BS, King OD, Gitler AD, Shorter J. 2010. Prion-like disorders: Blurring the divide between transmissibility and infectivity. J Cell Sci 123: 1191-1201.

Da Cruz S, Cleveland DW. 2011. Understanding the role of TDP-43 and FUS/TLS in ALS and beyond. Curr Opin Neurobiol 21: 904-919.

D’Ambrogio A, Buratti E, Stuani C, Guarnaccia C, Romano M, Ayala YM, Baralle FE. 2009. Functional mapping of the interaction between TDP-43 and hnRNP A2 in vivo. Nucleic Acids Res 37: 4116-4126.

Das I, Krzyzosiak A, Schneider K, Wrabetz L, D’Antonio M, Barry N, Sigurdardottir A, Bertolotti A. 2015. Preventing proteostasis diseases by selective inhibition of a phosphatase regulatory subunit. Science 348: 239-242.

Davidson Y, Kelley T, Mackenzie IR, Pickering-Brown S, Du Plessis D, Neary D, Snowden JS, Mann DM. 2007. Ubiquitinated pathological lesions in frontotemporal lobar degeneration contain the TAR DNA-binding protein, TDP-43. Acta Neuropathol 113: 521-533.
TDP-43: Biology, Pathobiology, and Therapeutics

DeJesus-Hernandez M, Mackenzie IR, Boeve BF, Boxer AL, Baker M, Rutherford NJ, Nicholson AM, Finch NA, Flynn H, Adamson J, et al. 2011. Expanded GGGGCC hexanucleotide repeat in noncoding region of C9ORF72 causes chromosome 9p-linked FTD and ALS. Neuron 72: 245-256.

Deleault NR, Lucassen RW, Supattapone S. 2003. RNA molecules stimulate prion protein conversion. Nature 425: 717-720.

Deng HX, Zhai H, Bigio EH, Yan J, Fecto F, Ajroud K, Mishra M, Ajroud-Driss S, Heller S, Sufit R, et al. 2010. FUSimmunoreactive inclusions are a common feature in sporadic and non-SOD1 familial amyotrophic lateral sclerosis. Ann Neurol 67: 739-748.

Deng HX, Chen W, Hong ST, Boycott KM, Gorrie GH, Siddique N, Yang Y, Fecto F, Shi Y, Zhai H, et al. 2011. Mutations in UBQLN2 cause dominant X-linked juvenile and adult-onset ALS and ALS/dementia. Nature 477: 211-215.

Drisaldi B, Colnaghi L, Fioriti L, Rao N, Myers C, Snyder AM, Metzger DJ, Tarasoff J, Konstantinov E, Fraser PE, et al. 2015. SUMOylation is an inhibitory constraint that regulates the prion-like aggregation and activity of CPEB3. Cell Rep 11: 1694-1702.

Duennwald ML, Shorter J. 2010. Countering amyloid polymorphism and drug resistance with minimal drug cocktails. Prion 4: 244-251.

Duennwald ML, Echeverria A, Shorter J. 2012. Small heat shock proteins potentiate amyloid dissolution by protein disaggregases from yeast and humans. PLoS Biol 10: e1001346.

Eisenberg D, Jucker M. 2012. The amyloid state of proteins in human diseases. Cell 148: 1188-1203.

Elden AC, Kim HJ, Hart MP, Chen-Plotkin AS, Johnson BS, Fang X, Armakola M, Geser F, Greene R, Lu MM, et al. 2010. Ataxin-2 intermediate-length polyglutamine expansions are associated with increased risk for ALS. $\mathrm{Na}$ ture 466: 1069-1075.

Erives AJ, Fassler JS. 2015. Metabolic and chaperone gene loss marks the origin of animals: Evidence for Hsp104 and Hsp78 chaperones sharing mitochondrial enzymes as clients. PLoS ONE 10: e0117192.

Estes PS, Boehringer A, Zwick R, Tang JE, Grigsby B, Zarnescu DC. 2011. Wild-type and A315T mutant TDP-43 exert differential neurotoxicity in a Drosophila model of ALS. Hum Mol Genet 20: 2308-2321.

Fang YS, Tsai KJ, Chang YJ, Kao P, Woods R, Kuo PH, Wu CC, Liao JY, Chou SC, Lin V, et al. 2014. Full-length TDP43 forms toxic amyloid oligomers that are present in frontotemporal lobar dementia-TDP patients. Nat Commun 5: 4824.

Feiguin F, Godena VK, Romano G, D’Ambrogio A, Klima R, Baralle FE. 2009. Depletion of TDP-43 affects Drosophila motoneurons terminal synapsis and locomotive behavior. FEBS Lett 583: 1586-1592.

Feiler MS, Strobel B, Freischmidt A, Helferich AM, Kappel J, Brewer BM, Li D, Thal DR, Walther P, Ludolph AC, et al. 2015. TDP-43 is intercellularly transmitted across axon terminals. J Cell Biol 211: 897-911.

Fiesel FC, Weber SS, Supper J, Zell A, Kahle PJ. 2012. TDP43 regulates global translational yield by splicing of exon 
junction complex component SKAR. Nucleic Acids Res 40: $2668-2682$.

Figley MD, Gitler AD. 2013. Yeast genetic screen reveals novel therapeutic strategy for ALS. Rare Dis 1: e24420.

Fioriti L, Myers C, Huang YY, Li X, Stephan JS, Trifilieff P, Colnaghi L, Kosmidis S, Drisaldi B, Pavlopoulos E, et al. 2015. The persistence of hippocampal-based memory requires protein synthesis mediated by the prion-like protein CPEB3. Neuron 86: 1433-1448.

Ford AF, Shorter J. 2015. Fleeting amyloid-like forms of Rim4 ensure meiotic fidelity. Cell 163: 275-276.

Fox BW, Tibbetts RS. 2015. Neurodegeneration: Problems at the nuclear pore. Nature 525: 36-37.

Freibaum BD, Chitta RK, High AA, Taylor JP. 2010. Global analysis of TDP-43 interacting proteins reveals strong association with RNA splicing and translation machinery. J Proteome Res 9: 1104-1120.

Freibaum BD, Lu Y, Lopez-Gonzalez R, Kim NC, Almeida S, Lee KH, Badders N, Valentine M, Miller BL, Wong PC, et al. 2015. GGGGCC repeat expansion in C9orf72 compromises nucleocytoplasmic transport. Nature 525: 129 133.

Fuentealba RA, Udan M, Bell S, Wegorzewska I, Shao J, Diamond MI, Weihl CC, Baloh RH. 2010. Interaction with polyglutamine aggregates reveals a $\mathrm{Q} / \mathrm{N}$-rich domain in TDP-43. J Biol Chem 285: 26304-26314.

Fujita Y, Fujita S, Takatama M, Ikeda M, Okamoto K. 2011. Numerous FUS-positive inclusions in an elderly woman with motor neuron disease. Neuropathology 31: 170-176.

Furukawa Y, Kaneko K, Watanabe S, Yamanaka K, Nukina N. 2011. A seeding reaction recapitulates intracellular formation of Sarkosyl-insoluble transactivation response element (TAR) DNA-binding protein-43 inclusions. J Biol Chem 286: 18664-18672.

Gao X, Carroni M, Nussbaum-Krammer C, Mogk A, Nillegoda NB, Szlachcic A, Guilbride DL, Saibil HR, Mayer MP, Bukau B. 2015. Human Hsp70 disaggregase reverses parkinson's-linked $\alpha$-synuclein amyloid fibrils. Mol Cell 59: 781-793.

Geser F, Martinez-Lage M, Robinson J, Uryu K, Neumann M, Brandmeir NJ, Xie SX, Kwong LK, Elman L, McCluskey L, et al. 2009. Clinical and pathological continuum of multisystem TDP-43 proteinopathies. Arch Neurol 66: $180-189$.

Gispert S, Kurz A, Waibel S, Bauer P, Liepelt I, Geisen C, Gitler AD, Becker T, Weber M, Berg D, et al. 2012. The modulation of amyotrophic lateral sclerosis risk by ataxin- 2 intermediate polyglutamine expansions is a specific effect. Neurobiol Dis 45: 356-361.

Gitcho MA, Baloh RH, Chakraverty S, Mayo K, Norton JB, Levitch D, Hatanpaa KJ, White CL III, Bigio EH, Caselli $\mathrm{R}$, et al. 2008. TDP-43 A315T mutation in familial motor neuron disease. Ann Neurol 63: 535-538.

Gitcho MA, Bigio EH, Mishra M, Johnson N, Weintraub S, Mesulam M, Rademakers R, Chakraverty S, Cruchaga C, Morris JC, et al. 2009. TARDBP 3 '-UTR variant in autopsy-confirmed frontotemporal lobar degeneration with TDP-43 proteinopathy. Acta Neuropathol 118: 633-645.

Gitler AD, Shorter J. 2011. RNA-binding proteins with prion-like domains in ALS and FTLD-U. Prion 5: 179-187.
Goldschmidt L, Teng PK, Riek R, Eisenberg D. 2010. Identifying the amylome, proteins capable of forming amyloid-like fibrils. Proc Natl Acad Sci 107: 3487-3492.

Grabbe C, Dikic I. 2009. Functional roles of ubiquitin-like domain (ULD) and ubiquitin-binding domain (UBD) containing proteins. Chem Rev 109: 1481-1494.

Grad LI, Fernando SM, Cashman NR. 2015. From molecule to molecule and cell to cell: Prion-like mechanisms in amyotrophic lateral sclerosis. Neurobiol Dis 77: 257-265.

Gros-Louis F, Gaspar C, Rouleau GA. 2006. Genetics of familial and sporadic amyotrophic lateral sclerosis. Biochim Biophys Acta 1762: 956-972.

Guo L, Shorter J. 2015. It's raining liquids: RNA tunes viscoelasticity and dynamics of membraneless organelles. Mol Cell 60: 189-192.

Guo W, Chen Y, Zhou X, Kar A, Ray P, Chen X, Rao EJ, Yang M, Ye H, Zhu L, et al. 2011. An ALS-associated mutation affecting TDP-43 enhances protein aggregation, fibril formation and neurotoxicity. Nat Struct Mol Biol 18: $822-830$.

Haines JD, Herbin O, de la Hera B, Vidaurre OG, Moy GA, Sun Q, Fung HY, Albrecht S, Alexandropoulos K, McCauley D, et al. 2015. Nuclear export inhibitors avert progression in preclinical models of inflammatory demyelination. Nat Neurosci 18: 511-520.

Halfmann R, Jarosz DF, Jones SK, Chang A, Lancaster AK, Lindquist S. 2012. Prions are a common mechanism for phenotypic inheritance in wild yeasts. Nature 482: $363-$ 368.

Halliday M, Radford H, Sekine Y, Moreno J, Verity N, le Quesne J, Ortori CA, Barrett DA, Fromont C, Fischer PM, et al. 2015. Partial restoration of protein synthesis rates by the small molecule ISRIB prevents neurodegeneration without pancreatic toxicity. Cell Death Dis 6: e1672.

Hammarstrom P, Wiseman RL, Powers ET, Kelly JW. 2003. Prevention of transthyretin amyloid disease by changing protein misfolding energetics. Science 299: 713-716.

Han TW, Kato M, Xie S, Wu LC, Mirzaei H, Pei J, Chen M, Xie Y, Allen J, Xiao G, et al. 2012. Cell-free formation of RNA granules: Bound RNAs identify features and components of cellular assemblies. Cell 149: 768-779.

Hanson KA, Kim SH, Wassarman DA, Tibbetts RS. 2010. Ubiquilin modifies TDP-43 toxicity in a Drosophila model of amyotrophic lateral sclerosis (ALS). J Biol Chem 285: 11068-11072.

Harding HP, Zeng H, Zhang Y, Jungries R, Chung P, Plesken H, Sabatini DD, Ron D. 2001. Diabetes mellitus and exocrine pancreatic dysfunction in perk $-/-$ mice reveals a role for translational control in secretory cell survival. Mol Cell 7: 1153-1163.

Hart MP, Gitler AD. 2012. ALS-associated ataxin 2 polyQ expansions enhance stress-induced caspase 3 activation and increase TDP-43 pathological modifications. J Neurosci 32: 9133-9142.

Hart MP, Brettschneider J, Lee VM, Trojanowski JQ, Gitler AD. 2012. Distinct TDP-43 pathology in ALS patients with ataxin 2 intermediate-length polyQ expansions. Acta Neuropathol 124: 221-230.

Hewitt C, Kirby J, Highley JR, Hartley JA, Hibberd R, Hollinger HC, Williams TL, Ince PG, McDermott CJ, Shaw 
TDP-43: Biology, Pathobiology, and Therapeutics

PJ. 2010. Novel FUS/TLS mutations and pathology in familial and sporadic amyotrophic lateral sclerosis. Arch Neurol 67: 455-461.

Huang YC, Lin KF, He RY, Tu PH, Koubek J, Hsu YC, Huang JJ. 2013. Inhibition of TDP-43 aggregation by nucleic acid binding. PLOS ONE 8: e64002.

Hurshman AR, White JT, Powers ET, Kelly JW. 2004. Transthyretin aggregation under partially denaturing conditions is a downhill polymerization. Biochemistry 43: 7365-7381.

Igaz LM, Kwong LK, Lee EB, Chen-Plotkin A, Swanson E, Unger T, Malunda J, Xu Y, Winton MJ, Trojanowski JQ, et al. 2011. Dysregulation of the ALS-associated gene TDP43 leads to neuronal death and degeneration in mice. $J$ Clin Invest 121: 726-738.

Iguchi Y, Katsuno M, Niwa J, Takagi S, Ishigaki S, Ikenaka K, Kawai K, Watanabe H, Yamanaka K, Takahashi R, et al. 2013. Loss of TDP-43 causes age-dependent progressive motor neuron degeneration. Brain 136: 1371-1382.

Imbert G, Saudou F, Yvert G, Devys D, Trottier Y, Garnier JM, Weber C, Mandel JL, Cancel G, Abbas N, et al. 1996. Cloning of the gene for spinocerebellar ataxia 2 reveals a locus with high sensitivity to expanded CAG/glutamine repeats. Nat Genet 14: 285-291.

Irwin DJ, Cairns NJ, Grossman M, McMillan CT, Lee EB, Van Deerlin VM, Lee VM, Trojanowski JQ. 2015. Frontotemporal lobar degeneration: Defining phenotypic diversity through personalized medicine. Acta Neuropathol 129: 469-491.

Jablonski MR, Markandaiah SS, Jacob D, Meng NJ, Li K, Gennaro V, Lepore AC, Trotti D, Pasinelli P. 2014. Inhibiting drug efflux transporters improves efficacy of ALS therapeutics. Ann Clin Transl Neurol 1: 996-1005.

Jackrel ME, Shorter J. 2014a. Potentiated Hsp104 variants suppress toxicity of diverse neurodegenerative diseaselinked proteins. Dis Model Mech 7: 1175-1184.

Jackrel ME, Shorter J. 2014b. Reversing deleterious protein aggregation with re-engineered protein disaggregases. Cell Cycle 13: 1379-1383.

Jackrel ME, Shorter J. 2015. Engineering enhanced protein disaggregases for neurodegenerative disease. Prion 9: 90109.

Jackrel ME, DeSantis ME, Martinez BA, Castellano LM, Stewart RM, Caldwell KA, Caldwell GA, Shorter J. 2014a. Potentiated Hsp104 variants antagonize diverse proteotoxic misfolding events. Cell 156: 170-182.

Jackrel ME, Tariq A, Yee K, Weitzman R, Shorter J. 2014b. Isolating potentiated Hsp104 variants using yeast proteinopathy models. J Vis Exp 93: e52089.

Jain S, Wheeler JR, Walters RW, Agrawal A, Barsic A, Parker R. 2016. ATPase-modulated stress granules contain a diverse proteome and substructure. Cell 164: 487-498.

Johnson BS, McCaffery JM, Lindquist S, Gitler AD. 2008. A yeast TDP-43 proteinopathy model: Exploring the molecular determinants of TDP-43 aggregation and cellular toxicity. Proc Natl Acad Sci 105: 6439-6444.

Johnson BS, Snead D, Lee JJ, McCaffery JM, Shorter J, Gitler AD. 2009. TDP-43 is intrinsically aggregation-prone, and amyotrophic lateral sclerosis-linked mutations accelerate aggregation and increase toxicity. $J$ Biol Chem 284: 20329-20339.
Johnson JO, Mandrioli J, Benatar M, Abramzon Y, Van Deerlin VM, Trojanowski JQ, Gibbs JR, Brunetti M, Gronka S, Wuu J, et al. 2010. Exome sequencing reveals VCP mutations as a cause of familial ALS. Neuron 68: 857-864.

Josephs KA, Murray ME, Whitwell JL, Parisi JE, Petrucelli L, Jack CR, Petersen RC, Dickson DW. 2014a. Staging TDP43 pathology in Alzheimer's disease. Acta Neuropathol 127: $441-450$.

Josephs KA, Whitwell JL, Weigand SD, Murray ME, Tosakulwong N, Liesinger AM, Petrucelli L, Senjem ML, Knopman DS, Boeve BF, et al. 2014b. TDP-43 is a key player in the clinical features associated with Alzheimer's disease. Acta Neuropathol 127: 811-824.

Josephs KA, Murray ME, Whitwell JL, Tosakulwong N, Weigand SD, Petrucelli L, Liesinger AM, Petersen RC, Parisi JE, Dickson DW. 2016. Updated TDP-43 in Alzheimer's disease staging scheme. Acta Neuropathol 131: 571-585.

Jovicic A, Gitler AD. 2014. TDP-43 in ALS: Stay on target . . almost there. Neuron 81: 463-465.

Jovicic A, Mertens J, Boeynaems S, Bogaert E, Chai N, Yamada SB, Paul JW 3rd, Sun S, Herdy JR, Bieri G, et al. 2015. Modifiers of C9orf72 dipeptide repeat toxicity connect nucleocytoplasmic transport defects to FTD/ALS. Nat Neurosci 18: 1226-1229.

Jung Y, Dickson DW, Murray ME, Whitwell JL, Knopman DS, Boeve BF, Jack CR Jr, Parisi JE, Petersen RC, Josephs KA. 2014. TDP-43 in Alzheimer's disease is not associated with clinical FTLD or Parkinsonism. J Neurol 261: 13441348.

Kabashi E, Valdmanis PN, Dion P, Spiegelman D, McConkey BJ, Vande Velde C, Bouchard JP, Lacomblez L, Pochigaeva $\mathrm{K}$, Salachas F, et al. 2008. TARDBP mutations in individuals with sporadic and familial amyotrophic lateral sclerosis. Nat Genet 40: 572-574.

Kabashi E, Lin L, Tradewell ML, Dion PA, Bercier V, Bourgouin P, Rochefort D, Bel Hadj S, Durham HD, Vande Velde C, et al. 2010. Gain and loss of function of ALSrelated mutations of TARDBP (TDP-43) cause motor deficits in vivo. Hum Mol Genet 19: 671-683.

Kato M, Han TW, Xie S, Shi K, Du X, Wu LC, Mirzaei H, Goldsmith EJ, Longgood J, Pei J, et al. 2012. Cell-free formation of RNA granules: Low complexity sequence domains form dynamic fibers within hydrogels. Cell 149: $753-767$.

Kawahara Y, Mieda-Sato A. 2012. TDP-43 promotes microRNA biogenesis as a component of the Drosha and Dicer complexes. Proc Natl Acad Sci 109: 3347-3352.

Kayed R, Head E, Thompson JL, McIntire TM, Milton SC, Cotman CW, Glabe CG. 2003. Common structure of soluble amyloid oligomers implies common mechanism of pathogenesis. Science 300: 486-489.

Khan MR, Li L, Perez-Sanchez C, Saraf A, Florens L, Slaughter BD, Unruh JR, Si K. 2015. Amyloidogenic oligomerization transforms Drosophila Orb2 from a translation repressor to an activator. Cell 163: 1468-1483.

Kiehl TR, Nechiporuk A, Figueroa KP, Keating MT, Huynh DP, Pulst SM. 2006. Generation and characterization of Sca2 (ataxin-2) knockout mice. Biochem Biophys Res Commun 339: 17-24.

Kim SH, Shanware NP, Bowler MJ, Tibbetts RS. 2010. Amyotrophic lateral sclerosis-associated proteins TDP- 
L. Guo and J. Shorter

43 and FUS/TLS function in a common biochemical complex to co-regulate HDAC6 mRNA. J Biol Chem 285: 34097-34105.

Kim HJ, Kim NC, Wang YD, Scarborough EA, Moore J, Diaz Z, MacLea KS, Freibaum B, Li S, Molliex A, et al. 2013. Mutations in prion-like domains in hnRNPA2B1 and hnRNPA1 cause multisystem proteinopathy and ALS. Nature 495: 467-473.

Kim HJ, Raphael AR, LaDow ES, McGurk L, Weber RA, Trojanowski JQ, Lee VM, Finkbeiner S, Gitler AD, Bonin NM. 2014. Therapeutic modulation of eIF2 $\alpha$ phosphorylation rescues TDP-43 toxicity in amyotrophic lateral sclerosis disease models. Nat Genet 46: 152-160.

King OD, Gitler AD, Shorter J. 2012. The tip of the iceberg: RNA-binding proteins with prion-like domains in neurodegenerative disease. Brain Res 1462: 61-80.

Kraemer BC, Schuck T, Wheeler JM, Robinson LC, Trojanowski JQ, Lee VM, Schellenberg GD. 2010. Loss of murine TDP-43 disrupts motor function and plays an essential role in embryogenesis. Acta Neuropathol 119: 409419.

Kroschwald S, Maharana S, Mateju D, Malinovska L, Nuske E, Poser I, Richter D, Alberti S. 2015. Promiscuous interactions and protein disaggregases determine the material state of stress-inducible RNP granules. eLife 4: e06807.

Kuo PH, Chiang CH, Wang YT, Doudeva LG, Yuan HS 2014. The crystal structure of TDP-43 RRM1-DNA complex reveals the specific recognition for UG- and TG-rich nucleic acids. Nucleic Acids Res 42: 4712-4722.

Kwiatkowski TJ Jr, Bosco DA, Leclerc AL, Tamrazian E, Vanderburg CR, Russ C, Davis A, Gilchrist J, Kasarskis EJ, Munsat T, et al. 2009. Mutations in the FUS/TLS gene on chromosome 16 cause familial amyotrophic lateral sclerosis. Science 323: 1205-1208.

Kwon I, Xiang S, Kato M, Wu L, Theodoropoulos P, Wang T, Kim J, Yun J, Xie Y, McKnight SL. 2014. Poly-dipeptides encoded by the C9orf72 repeats bind nucleoli, impede RNA biogenesis, and kill cells. Science 345: 1139-1145.

Kwong LK, Uryu K, Trojanowski JQ, Lee VM. 2008. TDP-43 proteinopathies: Neurodegenerative protein misfolding diseases without amyloidosis. Neurosignals 16: 41-51.

Lagier-Tourenne C, Cleveland DW. 2009. Rethinking ALS: The FUS about TDP-43. Cell 136: 1001-1004.

Lagier-Tourenne C, Polymenidou M, Cleveland DW. 2010. TDP-43 and FUS/TLS: Emerging roles in RNA processing and neurodegeneration. Hum Mol Genet 19: R46R64.

Lagier-Tourenne C, Polymenidou M, Hutt KR, Vu AQ, Baughn M, Huelga SC, Clutario KM, Ling SC, Liang TY, Mazur C, et al. 2012. Divergent roles of ALS-linked proteins FUS/TLS and TDP-43 intersect in processing long pre-mRNAs. Nat Neurosci 15: 1488-1497.

Lalmansingh AS, Urekar CJ, Reddi PP. 2011. TDP-43 is a transcriptional repressor: The testis-specific mouse acrv1 gene is a TDP-43 target in vivo. J Biol Chem 286: 1097010982.

Lashuel HA, Hartley D, Petre BM, Walz T, Lansbury PT Jr. 2002. Neurodegenerative disease: Amyloid pores from pathogenic mutations. Nature 418: 291.

Lastres-Becker I, Brodesser S, Lutjohann D, Azizov M, Buchmann J, Hintermann E, Sandhoff K, Schurmann A, No- wock J, Auburger G. 2008. Insulin receptor and lipid metabolism pathology in ataxin-2 knock-out mice. Hum Mol Genet 17: 1465-1481.

Lattante S, Rouleau GA, Kabashi E. 2013. TARDBP and FUS mutations associated with amyotrophic lateral sclerosis: Summary and update. Hum Mutat 34: 812-826.

Lee T, Li YR, Chesi A, Hart MP, Ramos D, Jethava N, Hosangadi D, Epstein J, Hodges B, Bonini NM, et al. 2011a. Evaluating the prevalence of polyglutamine repeat expansions in amyotrophic lateral sclerosis. Neurology 76: 2062-2065.

Lee T, Li YR, Ingre C, Weber M, Grehl T, Gredal O, de Carvalho M, Meyer T, Tysnes OB, Auburger G, et al. 2011b. Ataxin-2 intermediate-length polyglutamine expansions in European ALS patients. Hum Mol Genet 20: 1697-1700.

Lee EB, Lee VM, Trojanowski JQ. 2012. Gains or losses: Molecular mechanisms of TDP43-mediated neurodegeneration. Nat Rev Neurosci 13: 38-50.

Legname G, Baskakov IV, Nguyen HO, Riesner D, Cohen FE, DeArmond SJ, Prusiner SB. 2004. Synthetic mammalian prions. Science 305: 673-676.

Li Y, Ray P, Rao EJ, Shi C, Guo W, Chen X, Woodruff EA III, Fushimi K, Wu JY. 2010. A Drosophila model for TDP-43 proteinopathy. Proc Natl Acad Sci 107: 3169-3174.

Li YR, King OD, Shorter J, Gitler AD. 2013. Stress granules as crucibles of ALS pathogenesis. J Cell Biol 201: 361372.

Lim L, Wei Y, Lu Y, Song J. 2016. ALS-causing mutations significantly perturb the self-assembly and interaction with nucleic acid of the intrinsically disordered prionlike domain of TDP-43. PLoS Biol 14: e1002338.

Lin Y, Protter DS, Rosen MK, Parker R. 2015. Formation and maturation of phase-separated liquid droplets by RNAbinding proteins. Mol Cell 60: 208-219.

Ling SC, Albuquerque CP, Han JS, Lagier-Tourenne C, Tokunaga S, Zhou H, Cleveland DW. 2010. ALS-associated mutations in TDP-43 increase its stability and promote TDP-43 complexes with FUS/TLS. Proc Natl Acad Sci 107: $13318-13323$.

Ling SC, Polymenidou M, Cleveland DW. 2013. Converging mechanisms in ALS and FTD: Disrupted RNA and protein homeostasis. Neuron 79: 416-438.

Ling JP, Pletnikova O, Troncoso JC, Wong PC. 2015. TDP-43 repression of nonconserved cryptic exons is compromised in ALS-FTD. Science 349: 650-655.

Liu-Yesucevitz L, Bilgutay A, Zhang YJ, Vanderweyde T, Citro A, Mehta T, Zaarur N, McKee A, Bowser R, Sherman M, et al. 2010. Tar DNA binding protein-43 (TDP43) associates with stress granules: Analysis of cultured cells and pathological brain tissue. PLoS ONE 5: e13250.

Liu-Yesucevitz L, Bassell GJ, Gitler AD, Hart AC, Klann E, Richter JD, Warren ST, Wolozin B. 2011. Local RNA translation at the synapse and in disease. J Neurosci 31: 16086-16093.

Liu-Yesucevitz L, Lin AY, Ebata A, Boon JY, Reid W, Xu YF, Kobrin K, Murphy GJ, Petrucelli L, Wolozin B. 2014 ALS-linked mutations enlarge TDP-43-enriched neuronal RNA granules in the dendritic arbor. J Neurosci 34: 4167-4174. 
Lorenzetti D, Bohlega S, Zoghbi HY. 1997. The expansion of the CAG repeat in ataxin-2 is a frequent cause of autosomal dominant spinocerebellar ataxia. Neurology 49: 1009-1013.

Lu Y, Ferris J, Gao FB. 2009. Frontotemporal dementia and amyotrophic lateral sclerosis-associated disease protein TDP-43 promotes dendritic branching. Mol Brain 2: 30.

Ludolph AC, Brettschneider J. 2015. TDP-43 in amyotrophic lateral sclerosis-Is it a prion disease? Eur J Neurol 22: $753-761$.

Luk KC, Kehm V, Carroll J, Zhang B, O'Brien P, Trojanowski JQ, Lee VM. 2012. Pathological $\alpha$-synuclein transmission initiates Parkinson-like neurodegeneration in nontransgenic mice. Science 338: 949-953.

Lukavsky PJ, Daujotyte D, Tollervey JR, Ule J, Stuani C, Buratti E, Baralle FE, Damberger FF, Allain FH. 2013. Molecular basis of UG-rich RNA recognition by the human splicing factor TDP-43. Nat Struct Mol Biol 20: 1443-1449.

Mackenzie IR, Neumann M. 2012. FET proteins in frontotemporal dementia and amyotrophic lateral sclerosis. Brain Res 1462: 40-43.

* Mackenzie IRA, Neumann M. 2017. Fused in sarcoma neuropathology in neurodegenerative disease. Cold Spring Harb Perspect Med doi: 10.1101/cshperspect.a024299.

Mackenzie IR, Bigio EH, Ince PG, Geser F, Neumann M, Cairns NJ, Kwong LK, Forman MS, Ravits J, Stewart H, et al. 2007. Pathological TDP-43 distinguishes sporadic amyotrophic lateral sclerosis from amyotrophic lateral sclerosis with SOD1 mutations. Ann Neurol 61: 427-434.

Mackenzie IR, Rademakers R, Neumann M. 2010. TDP-43 and FUS in amyotrophic lateral sclerosis and frontotemporal dementia. Lancet Neurol 9: 995-1007.

Mackenzie IR, Arzberger T, Kremmer E, Troost D, Lorenzl S, Mori K, Weng SM, Haass C, Kretzschmar HA, Edbauer D, et al. 2013. Dipeptide repeat protein pathology in C9ORF72 mutation cases: Clinico-pathological correlations. Acta Neuropathol 126: 859-879.

Madsen L, Schulze A, Seeger M, Hartmann-Petersen R. 2007. Ubiquitin domain proteins in disease. BMC Biochem 8: S1.

Majumdar A, Cesario WC, White-Grindley E, Jiang H, Ren F, Khan MR, Li L, Choi EM, Kannan K, Guo F, et al. 2012. Critical role of amyloid-like oligomers of Drosophila Orb2 in the persistence of memory. Cell 148: 515-529.

Mangus DA, Amrani N, Jacobson A. 1998. Pbplp, a factor interacting with Saccharomyces cerevisiae poly(A)-binding protein, regulates polyadenylation. Mol Cell Biol 18: 7383-7396.

Maniecka Z, Polymenidou M. 2015. From nucleation to widespread propagation: A prion-like concept for ALS. Virus Res 207: 94-105.

March ZM, King OD, Shorter J. 2016. Prion-like domains as epigenetic regulators, scaffolds for subcellular organization, and drivers of neurodegenerative disease. Brain Res 1647: 9-18.

Mattoo RU, Sharma SK, Priya S, Finka A, Goloubinoff P. 2013. Hsp110 is a bona fide chaperone using ATP to unfold stable misfolded polypeptides and reciprocally collaborate with Hsp70 to solubilize protein aggregates. J Biol Chem 288: 21399-21411.
TDP-43: Biology, Pathobiology, and Therapeutics

May S, Hornburg D, Schludi MH, Arzberger T, Rentzsch K, Schwenk BM, Grasser FA, Mori K, Kremmer E, BanzhafStrathmann J, et al. 2014. C9orf72 FTLD/ALS-associated Gly-Ala dipeptide repeat proteins cause neuronal toxicity and Unc119 sequestration. Acta Neuropathol 128: 485503.

McDonald KK, Aulas A, Destroismaisons L, Pickles S, Beleac E, Camu W, Rouleau GA, Vande Velde C. 2011. TAR DNA-binding protein 43 (TDP-43) regulates stress granule dynamics via differential regulation of G3BP and TIA1. Hum Mol Genet 20: 1400-1410.

Mizielinska S, Gronke S, Niccoli T, Ridler CE, Clayton EL, Devoy A, Moens T, Norona FE, Woollacott IO, Pietrzyk J, et al. 2014. C9orf72 repeat expansions cause neurodegeneration in Drosophila through arginine-rich proteins. Science 345: 1192-1194.

Molliex A, Temirov J, Lee J, Coughlin M, Kanagaraj AP, Kim HJ, Mittag T, Taylor JP. 2015. Phase separation by low complexity domains promotes stress granule assembly and drives pathological fibrillization. Cell 163: 123-133.

Mompean M, Romano V, Pantoja-Uceda D, Stuani C, Baralle FE, Buratti E, Laurents DV. 2016. The TDP-43 Nterminal domain structure at high resolution. FEBS $J$ 283: $1242-1260$.

Moreno JA, Radford H, Peretti D, Steinert JR, Verity N, Martin MG, Halliday M, Morgan J, Dinsdale D, Ortori CA, et al. 2012. Sustained translational repression by eIF $2 \alpha-P$ mediates prion neurodegeneration. Nature 485: $507-511$.

Moreno JA, Halliday M, Molloy C, Radford H, Verity N, Axten JM, Ortori CA, Willis AE, Fischer PM, Barrett DA, et al. 2013. Oral treatment targeting the unfolded protein response prevents neurodegeneration and clinical disease in prion-infected mice. Sci Transl Med 5: 206ra138.

Mori K, Arzberger T, Grasser FA, Gijselinck I, May S, Rentzsch K, Weng SM, Schludi MH, van der Zee J, Cruts $\mathrm{M}$, et al. 2013a. Bidirectional transcripts of the expanded C9orf72 hexanucleotide repeat are translated into aggregating dipeptide repeat proteins. Acta Neuropathol 126: 881-893.

Mori K, Lammich S, Mackenzie IR, Forne I, Zilow S, Kretzschmar H, Edbauer D, Janssens J, Kleinberger G, Cruts M, et al. 2013b. hnRNP A3 binds to GGGGCC repeats and is a constituent of p62-positive/TDP43-negative inclusions in the hippocampus of patients with C9orf72 mutations. Acta Neuropathol 125: 413-423.

Mori K, Weng SM, Arzberger T, May S, Rentzsch K, Kremmer E, Schmid B, Kretzschmar HA, Cruts M, Van Broeckhoven C, et al. 2013c. The C9orf72 GGGGCC repeat is translated into aggregating dipeptide-repeat proteins in FTLD/ALS. Science 339: 1335-1338.

Mu TW, Ong DS, Wang YJ, Balch WE, Yates JR III, Segatori L, Kelly JW. 2008. Chemical and biological approaches synergize to ameliorate protein-folding diseases. Cell 134: 769-781.

Nakashima-Yasuda H, Uryu K, Robinson J, Xie SX, Hurtig H, Duda JE, Arnold SE, Siderowf A, Grossman M, Leverenz JB, et al. 2007. Co-morbidity of TDP-43 proteinopathy in Lewy body related diseases. Acta Neuropathol 114: $221-229$. 
Nencetti S, Rossello A, Orlandini E. 2013. Tafamidis (Vyndaqel): A light for FAP patients. ChemMedChem 8: $1617-1619$.

Neumann M, Sampathu DM, Kwong LK, Truax AC, Micsenyi MC, Chou TT, Bruce J, Schuck T, Grossman M, Clark $\mathrm{CM}$, et al. 2006. Ubiquitinated TDP-43 in frontotemporal lobar degeneration and amyotrophic lateral sclerosis. Science 314: 130-133.

Neumann M, Kwong LK, Sampathu DM, Trojanowski JQ, Lee VM. 2007. TDP-43 proteinopathy in frontotemporal lobar degeneration and amyotrophic lateral sclerosis: Protein misfolding diseases without amyloidosis. Arch Neurol 64: 1388-1394.

Neumann M, Rademakers R, Roeber S, Baker M, Kretzschmar HA, Mackenzie IR. 2009. A new subtype of frontotemporal lobar degeneration with FUS pathology. Brain 132: $2922-2931$

Neumann M, Bentmann E, Dormann D, Jawaid A, DeJesusHernandez M, Ansorge O, Roeber S, Kretzschmar HA, Munoz DG, Kusaka H, et al. 2011. FET proteins TAF15 and EWS are selective markers that distinguish FTLD with FUS pathology from amyotrophic lateral sclerosis with FUS mutations. Brain 134: 2595-2609.

Nillegoda NB, Kirstein J, Szlachcic A, Berynskyy M, Stank A, Stengel F, Arnsburg K, Gao X, Scior A, Aebersold R, et al. 2015. Crucial HSP70 co-chaperone complex unlocks metazoan protein disaggregation. Nature 524: 247-251.

Nishimoto Y, Ito D, Yagi T, Nihei Y, Tsunoda Y, Suzuki N. 2010. Characterization of alternative isoforms and inclusion body of the TAR DNA-binding protein-43. J Biol Chem 285: 608-619.

Nonaka T, Hasegawa M. 2017. TDP-43 prions. Cold Spring Harb Perspect Med doi: 10.1101/cshperspect.a024463.

Nonaka T, Masuda-Suzukake M, Arai T, Hasegawa Y, Akatsu H, Obi T, Yoshida M, Murayama S, Mann DM, Akiyama $\mathrm{H}$, et al. 2013. Prion-like properties of pathological TDP43 aggregates from diseased brains. Cell Rep 4: 124-134.

Ou SH, Wu F, Harrich D, Garcia-Martinez LF, Gaynor RB. 1995. Cloning and characterization of a novel cellular protein, TDP-43, that binds to human immunodeficiency virus type 1 TAR DNA sequence motifs. J Virol 69: 3584-3596.

Pasinelli P, Brown RH. 2006. Molecular biology of amyotrophic lateral sclerosis: Insights from genetics. Nat Rev Neurosci 7: 710-723.

Paul JW, Gitler AD. 2014. Cell biology. Clogging information flow in ALS. Science 345: 1118-1119.

Pesiridis GS, Lee VM, Trojanowski JQ. 2009. Mutations in TDP-43 link glycine-rich domain functions to amyotrophic lateral sclerosis. Hum Mol Genet 18: R156-R162.

Pesiridis GS, Tripathy K, Tanik S, Trojanowski JQ, Lee VM. 2011. A "two-hit" hypothesis for inclusion formation by carboxyl-terminal fragments of TDP-43 protein linked to RNA depletion and impaired microtubule-dependent transport. J Biol Chem 286: 18845-18855.

Polymenidou M, Cleveland DW. 2011. The seeds of neurodegeneration: Prion-like spreading in ALS. Cell 147: 498-508.

Polymenidou M, Cleveland DW. 2012. Prion-like spread of protein aggregates in neurodegeneration. J Exp Med 209: 889-893.
Polymenidou M, Lagier-Tourenne C, Hutt KR, Huelga SC, Moran J, Liang TY, Ling SC, Sun E, Wancewicz E, Mazur C, et al. 2011. Long pre-mRNA depletion and RNA missplicing contribute to neuronal vulnerability from loss of TDP-43. Nat Neurosci 14: 459-468.

Prusiner SB. 2013. Biology and genetics of prions causing neurodegeneration. Annu Rev Genet 47: 601-623.

Pulst SM, Nechiporuk A, Nechiporuk T, Gispert S, Chen XN, Lopes-Cendes I, Pearlman S, Starkman S, OrozcoDiaz G, Lunkes A, et al. 1996. Moderate expansion of a normally biallelic trinucleotide repeat in spinocerebellar ataxia type 2. Nat Genet 14: 269-276.

Qin H, Lim LZ, Wei Y, Song J. 2014. TDP-43 N terminus encodes a novel ubiquitin-like fold and its unfolded form in equilibrium that can be shifted by binding to ssDNA. Proc Natl Acad Sci 111: 18619-18624.

Rademakers R, Stewart H, Dejesus-Hernandez M, Krieger C, Graff-Radford N, Fabros M, Briemberg H, Cashman N, Eisen A, Mackenzie IR. 2010. Fus gene mutations in familial and sporadic amyotrophic lateral sclerosis. Muscle Nerve 42: 170-176.

Ramaswami M, Taylor JP, Parker R. 2013. Altered ribostasis: RNA-protein granules in degenerative disorders. Cell 154: $727-736$.

Rampelt H, Kirstein-Miles J, Nillegoda NB, Chi K, Scholz SR, Morimoto RI, Bukau B. 2012. Metazoan Hsp70 machines use Hsp110 to power protein disaggregation. EMBO J 31: 4221-4235.

Ravits JM, La Spada AR. 2009. ALS motor phenotype heterogeneity, focality, and spread: Deconstructing motor neuron degeneration. Neurology 73: 805-811.

Renton AE, Majounie E, Waite A, Simon-Sanchez J, Rollinson S, Gibbs JR, Schymick JC, Laaksovirta $\mathrm{H}$, van Swieten JC, Myllykangas L, et al. 2011. A hexanucleotide repeat expansion in C9ORF72 is the cause of chromosome 9p21-linked ALS-FTD. Neuron 72: 257-268.

Renton AE, Chio A, Traynor BJ. 2014. State of play in amyotrophic lateral sclerosis genetics. Nat Neurosci 17: 17-23.

Ritson GP, Custer SK, Freibaum BD, Guinto JB, Geffel D, Moore J, Tang W, Winton MJ, Neumann M, Trojanowski JQ, et al. 2010. TDP-43 mediates degeneration in a novel Drosophila model of disease caused by mutations in VCP/p97. J Neurosci 30: 7729-7739.

Robberecht W, Philips T. 2013. The changing scene of amyotrophic lateral sclerosis. Nat Rev Neurosci 14: 248-264.

Roberts BE, Duennwald ML, Wang H, Chung C, Lopreiato NP, Sweeny EA, Knight MN, Shorter J. 2009. A synergistic small-molecule combination directly eradicates diverse prion strain structures. Nat Chem Biol 5: 936-946.

Robinson JL, Geser F, Stieber A, Umoh M, Kwong LK, Van Deerlin VM, Lee VM, Trojanowski JQ. 2013. TDP-43 skeins show properties of amyloid in a subset of ALS cases. Acta Neuropathol 125: 121-131.

Rohrer JD, Isaacs AM, Mizielinska S, Mead S, Lashley T, Wray S, Sidle K, Fratta P, Orrell RW, Hardy J, et al. 2015. C9orf72 expansions in frontotemporal dementia and amyotrophic lateral sclerosis. Lancet Neurol 14: 291-301.

Romano V, Quadri Z, Baralle FE, Buratti E. 2015. The structural integrity of TDP-43 N-terminus is required for ef- 
TDP-43: Biology, Pathobiology, and Therapeutics

ficient aggregate entrapment and consequent loss of protein function. Prion 9: 1-9.

Rotunno MS, Bosco DA. 2013. An emerging role for misfolded wild-type SOD1 in sporadic ALS pathogenesis. Front Cell Neurosci 7: 253.

Rowland LP, Shneider NA. 2001. Amyotrophic lateral sclerosis. N Engl J Med 344: 1688-1700.

Saini A, Chauhan VS. 2011. Delineation of the core aggregation sequences of TDP-43 C-terminal fragment. Chembiochem 12: 2495-2501.

Saini A, Chauhan VS. 2014. Self-assembling properties of peptides derived from TDP-43 C-terminal fragment. Langmuir 30: 3845-3856.

Saldi TK, Ash PE, Wilson G, Gonzales P, Garrido-Lecca A, Roberts CM, Dostal V, Gendron TF, Stein LD, Blumenthal T, et al. 2014. TDP-1, the Caenorhabditis elegans ortholog of TDP-43, limits the accumulation of double-stranded RNA. EMBO J 33: 2947-2966.

Schmidt HB, Rohatgi R. 2016. In vivo formation of vacuolated multi-phase compartments lacking membranes. Cell Rep 16: $1228-1236$.

Schmid B, Hruscha A, Hogl S, Banzhaf-Strathmann J, Strecker K, van der Zee J, Teucke M, Eimer S, Hegermann J, Kittelmann M, et al. 2013. Loss of ALS-associated TDP43 in zebrafish causes muscle degeneration, vascular dysfunction, and reduced motor neuron axon outgrowth. Proc Natl Acad Sci 110: 4986-4991.

Schwab C, Arai T, Hasegawa M, Yu S, McGeer PL. 2008. Colocalization of transactivation-responsive DNA-binding protein 43 and huntingtin in inclusions of Huntington disease. J Neuropathol Exp Neurol 67: 1159-1165.

Scotter EL, Vance C, Nishimura AL, Lee YB, Chen HJ, Urwin H, Sardone V, Mitchell JC, Rogelj B, Rubinsztein DC, et al. 2014. Differential roles of the ubiquitin proteasome system and autophagy in the clearance of soluble and aggregated TDP-43 species. J Cell Sci 127: 1263-1278.

Seelaar H, Schelhaas HJ, Azmani A, Kusters B, Rosso S, Majoor-Krakauer D, de Rijik MC, Rizzu P, ten Brummelhuis M, van Doorn PA, et al. 2007. TDP-43 pathology in familial frontotemporal dementia and motor neuron disease without Progranulin mutations. Brain 130: 13751385.

Seelaar H, Klijnsma KY, de Koning I, van der Lugt A, Chiu WZ, Azmani A, Rozemuller AJ, van Swieten JC. 2010. Frequency of ubiquitin and FUS-positive, TDP-43-negative frontotemporal lobar degeneration. J Neurol 257: 747-753.

Sephton CF, Good SK, Atkin S, Dewey CM, Mayer P III, Herz J, Yu G. 2010. TDP-43 is a developmentally regulated protein essential for early embryonic development. $J$ Biol Chem 285: 6826-6834.

Sephton CF, Cenik C, Kucukural A, Dammer EB, Cenik B, Han Y, Dewey CM, Roth FP, Herz J, Peng J, et al. 2011. Identification of neuronal RNA targets of TDP-43-containing ribonucleoprotein complexes. J Biol Chem 286: 1204-1215.

Shaw CE. 2010. Capturing VCP: Another molecular piece in the ALS jigsaw puzzle. Neuron 68: 812-814.

Shiina Y, Arima K, Tabunoki H, Satoh J. 2010. TDP-43 dimerizes in human cells in culture. Cell Mol Neurobiol 30: $641-652$.
Shorter J. 2008. Hsp104: A weapon to combat diverse neurodegenerative disorders. Neurosignals 16: 63-74.

Shorter J. 2010. Emergence and natural selection of drugresistant prions. Mol Biosyst 6: 1115-1130.

Shorter J. 2011. The mammalian disaggregase machinery: Hsp110 synergizes with Hsp70 and Hsp40 to catalyze protein disaggregation and reactivation in a cell-free system. PLoS ONE 6: e26319.

Shorter J. 2016. Engineering therapeutic protein disaggregases. Mol Biol Cell 27: 1556-1560.

Shorter J, Lindquist S. 2005. Prions as adaptive conduits of memory and inheritance. Nat Rev Genet 6: 435-450.

Shorter J, Taylor JP. 2013. Disease mutations in the prionlike domains of hnRNPA1 and hnRNPA2/B1 introduce potent steric zippers that drive excess RNP granule assembly. Rare Dis 1: e25200.

Si K, Giustetto M, Etkin A, Hsu R, Janisiewicz AM, Miniaci MC, Kim JH, Zhu H, Kandel ER. 2003a. A neuronal isoform of CPEB regulates local protein synthesis and stabilizes synapse-specific long-term facilitation in aplysia. Cell 115: 893-904.

Si K, Lindquist S, Kandel ER. 2003b. A neuronal isoform of the aplysia CPEB has prion-like properties. Cell 115: 879-891.

Si K, Choi YB, White-Grindley E, Majumdar A, Kandel ER. 2010. Aplysia CPEB can form prion-like multimers in sensory neurons that contribute to long-term facilitation. Cell 140: 421-435.

Sidrauski C, Acosta-Alvear D, Khoutorsky A, Vedantham P, Hearn BR, Li H, Gamache K, Gallagher CM, Ang KK, Wilson C, et al. 2013. Pharmacological brake-release of mRNA translation enhances cognitive memory. eLife 2: e00498.

Sidrauski C, McGeachy AM, Ingolia NT, Walter P. 2015. The small molecule ISRIB reverses the effects of eIF $2 \alpha$ phosphorylation on translation and stress granule assembly. eLife 4: e05033.

Sreedharan J, Blair IP, Tripathi VB, Hu X, Vance C, Rogelj B, Ackerley S, Durnall JC, Williams KL, Buratti E, et al. 2008. TDP-43 mutations in familial and sporadic amyotrophic lateral sclerosis. Science 319: 1668-1672.

Stephan JS, Fioriti L, Lamba N, Colnaghi L, Karl K, Derkatch IL, Kandel ER. 2015. The CPEB3 protein is a functional prion that interacts with the actin cytoskeleton. Cell Rep 11: 1772-1785.

Sun S, Cleveland DW. 2012. TDP-43 toxicity and the usefulness of junk. Nat Genet 44: 1289-1291.

Sun Z, Diaz Z, Fang X, Hart MP, Chesi A, Shorter J, Gitler AD. 2011. Molecular determinants and genetic modifiers of aggregation and toxicity for the ALS disease protein FUS/TLS. PLoS Biol 9: e1000614.

Sun Y, Arslan PE, Won A, Yip CM, Chakrabartty A. 2014. Binding of TDP- 43 to the $3^{\prime}$ UTR of its cognate mRNA enhances its solubility. Biochemistry 53: 5885-5894.

Sweeny EA, Jackrel ME, Go MS, Sochor MA, Razzo BM, DeSantis ME, Gupta K, Shorter J. 2015. The hsp104 Nterminal domain enables disaggregase plasticity and potentiation. Mol Cell 57: 836-849.

Tan CF, Eguchi H, Tagawa A, Onodera O, Iwasaki T, Tsujino A, Nishizawa M, Kakita A, Takahashi H. 2007. TDP-43 immunoreactivity in neuronal inclusions in familial 
L. Guo and J. Shorter

amyotrophic lateral sclerosis with or without SOD1 gene mutation. Acta Neuropathol 113: 535-542.

Tao Z, Wang H, Xia Q, Li K, Li K, Jiang X, Xu G, Wang G, Ying Z. 2015. Nucleolar stress and impaired stress granule formation contribute to C9orf72 RAN translation-induced cytotoxicity. Hum Mol Genet 24: 2426-2441.

Thomas MG, Loschi M, Desbats MA, Boccaccio GL. 2011. RNA granules: The good, the bad and the ugly. Cell Signal 23: $324-334$.

Tollervey JR, Curk T, Rogelj B, Briese M, Cereda M, Kayikci M, Konig J, Hortobagyi T, Nishimura AL, Zupunski V, et al. 2011. Characterizing the RNA targets and positiondependent splicing regulation by TDP-43. Nat Neurosci 14: $452-458$.

Torrente MP, Shorter J. 2013. The metazoan protein disaggregase and amyloid depolymerase system: Hsp110, Hsp70, Hsp40, and small heat shock proteins. Prion 7: 457-463.

Torrente MP, Chuang E, Noll MM, Jackrel ME, Go MS, Shorter J. 2016. Mechanistic insights into Hsp104 potentiation. J Biol Chem 291: 5101-5115.

Tran H, Almeida S, Moore J, Gendron TF, Chalasani U, Lu Y, Du X, Nickerson JA, Petrucelli L, Weng Z, et al. 2015. Differential toxicity of nuclear RNA foci versus dipeptide repeat proteins in a Drosophila model of C9ORF72 FTD/ ALS. Neuron 87: 1207-1214.

Tsai KJ, Yang CH, Fang YH, Cho KH, Chien WL, Wang WT, Wu TW, Lin CP, Fu WM, Shen CK. 2010. Elevated expression of TDP-43 in the forebrain of mice is sufficient to cause neurological and pathological phenotypes mimicking FTLD-U. J Exp Med 207: 1661-1673.

Tsaytler P, Harding HP, Ron D, Bertolotti A. 2011. Selective inhibition of a regulatory subunit of protein phosphatase 1 restores proteostasis. Science 332: 91-94.

Udan M, Baloh RH. 2011. Implications of the prion-related $\mathrm{Q} / \mathrm{N}$ domains in TDP-43 and FUS. Prion 5: 1-5.

Uryu K, Nakashima-Yasuda H, Forman MS, Kwong LK, Clark CM, Grossman M, Miller BL, Kretzschmar HA, Lee VM, Trojanowski JQ, et al. 2008. Concomitant TAR-DNA-binding protein 43 pathology is present in Alzheimer disease and corticobasal degeneration but not in other tauopathies. J Neuropathol Exp Neurol 67: 555-564.

Vaccaro A, Patten SA, Aggad D, Julien C, Maios C, Kabashi E, Drapeau P, Parker JA. 2013. Pharmacological reduction of ER stress protects against TDP-43 neuronal toxicity in vivo. Neurobiol Dis 55: 64-75.

Valentine JS, Hart PJ. 2003. Misfolded CuZnSOD and amyotrophic lateral sclerosis. Proc Natl Acad Sci 100: 3617-3622.

Vance C, Rogelj B, Hortobagyi T, De Vos KJ, Nishimura AL, Sreedharan J, Hu X, Smith B, Ruddy D, Wright P, et al. 2009. Mutations in FUS, an RNA processing protein, cause familial amyotrophic lateral sclerosis type 6. Science 323: $1208-1211$.

Vieira NM, Naslavsky MS, Licinio L, Kok F, Schlesinger D, Vainzof M, Sanchez N, Kitajima JP, Gal L, Cavacana N, et al. 2014. A defect in the RNA-processing protein HNRPDL causes limb-girdle muscular dystrophy $1 \mathrm{G}$ (LGMD1G). Hum Mol Genet 23: 4103-4110.
Voigt A, Herholz D, Fiesel FC, Kaur K, Muller D, Karsten P, Weber SS, Kahle PJ, Marquardt T, Schulz JB. 2010. TDP43-mediated neuron loss in vivo requires RNA-binding activity. PLoS ONE 5: e12247.

Wainwright CE, Elborn JS, Ramsey BW, Marigowda G, Huang X, Cipolli M, Colombo C, Davies JC, De Boeck K, Flume PA, et al. 2015. Lumacaftor-Ivacaftor in patients with cystic fibrosis homozygous for Phe508del CFTR. N Engl J Med 373: 220-231.

Walker AK, Daniels CM, Goldman JE, Trojanowski JQ, Lee VM, Messing A. 2014. Astrocytic TDP-43 pathology in Alexander disease. J Neurosci 34: 6448-6458.

Walters RW, Muhlrad D, Garcia J, Parker R. 2015. Differential effects of Ydj1 and Sis1 on Hsp70-mediated clearance of stress granules in Saccharomyces cerevisiae. RNA 21: $1660-1671$.

Wang F, Wang X, Yuan CG, Ma J. 2010. Generating a prion with bacterially expressed recombinant prion protein. Science 327: 1132-1135.

Wang F, Wang X, Ma J. 2011a. Conversion of bacterially expressed recombinant prion protein. Methods 53: 208 213.

Wang F, Zhang Z, Wang X, Li J, Zha L, Yuan CG, Weissmann C, Ma J. 2011b. Genetic informational RNA is not required for recombinant prion infectivity. J Virol 86: 1874-1876.

Wang IF, Chang HY, Hou SC, Liou GG, Way TD, James Shen CK. 2012. The self-interaction of native TDP-43 C terminus inhibits its degradation and contributes to early proteinopathies. Nat Commun 3: 766.

Wang YT, Kuo PH, Chiang CH, Liang JR, Chen YR, Wang S, Shen JC, Yuan HS. 2013. The truncated C-terminal RNA recognition motif of TDP-43 protein plays a key role in forming proteinaceous aggregates. $J$ Biol Chem 288: 9049-9057.

Weihl CC, Temiz P, Miller SE, Watts G, Smith C, Forman M, Hanson PI, Kimonis V, Pestronk A. 2008. TDP-43 accumulation in inclusion body myopathy muscle suggests a common pathogenic mechanism with frontotemporal dementia. J Neurol Neurosurg Psychiatry 79: 1186-1189.

Wen X, Tan W, Westergard T, Krishnamurthy K, Markandaiah SS, Shi Y, Lin S, Shneider NA, Monaghan J, Pandey UB, et al. 2014. Antisense proline-arginine RAN dipeptides linked to C9ORF72-ALS/FTD form toxic nuclear aggregates that initiate in vitro and in vivo neuronal death. Neuron 84: 1213-1225.

Winton MJ, Igaz LM, Wong MM, Kwong LK, Trojanowski JQ, Lee VM. 2008. Disturbance of nuclear and cytoplasmic TAR DNA-binding protein (TDP-43) induces disease-like redistribution, sequestration, and aggregate formation. J Biol Chem 283: 13302-13309.

Wu LS, Cheng WC, Shen CK. 2012. Targeted depletion of TDP-43 expression in the spinal cord motor neurons leads to the development of amyotrophic lateral sclerosis-like phenotypes in mice. J Biol Chem 287: 2733527344.

Xu YF, Gendron TF, Zhang YJ, Lin WL, D'Alton S, Sheng H, Casey MC, Tong J, Knight J, Yu X, et al. 2010. Wild-type human TDP-43 expression causes TDP-43 phosphorylation, mitochondrial aggregation, motor deficits, and early mortality in transgenic mice. J Neurosci 30: 1085110859 . 
Yang C, Tan W, Whittle C, Qiu L, Cao L, Akbarian S, Xu Z 2010. The C-terminal TDP-43 fragments have a high aggregation propensity and harm neurons by a dominant-negative mechanism. PLoS ONE 5: e15878.

Yu Z, Zhu Y, Chen-Plotkin AS, Clay-Falcone D, McCluskey L, Elman L, Kalb RG, Trojanowski JQ, Lee VM, Van Deerlin VM, et al. 2011. PolyQ repeat expansions in ATXN2 associated with ALS are CAA interrupted repeats. PLOS ONE 6: e17951.

Zhang YJ, Xu YF, Cook C, Gendron TF, Roettges P, Link CD Lin WL, Tong J, Castanedes-Casey M, Ash P, et al. 2009. Aberrant cleavage of TDP-43 enhances aggregation and cellular toxicity. Proc Natl Acad Sci 106: 7607-7612.

Zhang T, Mullane PC, Periz G, Wang J. 2011. TDP-43 neurotoxicity and protein aggregation modulated by heat shock factor and insulin/IGF-1 signaling. Hum $\mathrm{Mol} \mathrm{Ge}$ net 20: 1952-1965.

Zhang T, Hwang HY, Hao H, Talbot C Jr, Wang J. 2012. Caenorhabditis elegans RNA-processing protein TDP-1 regulates protein homeostasis and life span. J Biol Chem 287: 8371-8382.

Zhang YJ, Caulfield T, Xu YF, Gendron TF, Hubbard J, Stetler C, Sasaguri H, Whitelaw EC, Cai S, Lee
TDP-43: Biology, Pathobiology, and Therapeutics

WC, et al. 2013. The dual functions of the extreme $\mathrm{N}$-terminus of TDP-43 in regulating its biological activity and inclusion formation. Hum Mol Genet 22: $3112-3122$.

Zhang K, Donnelly CJ, Haeusler AR, Grima JC, Machamer JB, Steinwald P, Daley EL, Miller SJ, Cunningham KM, Vidensky S, et al. 2015. The C9orf72 repeat expansion disrupts nucleocytoplasmic transport. Nature 525: 56-61.

Zinman L, Cudkowicz M. 2011. Emerging targets and treatments in amyotrophic lateral sclerosis. Lancet Neurol 10: 481-490.

Zu T, Gibbens B, Doty NS, Gomes-Pereira M, Huguet A, Stone MD, Margolis J, Peterson M, Markowski TW, Ingram MA, et al. 2011. Non-ATG-initiated translation directed by microsatellite expansions. Proc Natl Acad Sci 108: $260-265$.

Zu T, Liu Y, Banez-Coronel M, Reid T, Pletnikova O, Lewis J, Miller TM, Harms MB, Falchook AE, Subramony SH et al. 2013. RAN proteins and RNA foci from antisense transcripts in C9ORF72 ALS and frontotemporal dementia. Proc Natl Acad Sci 110: E4968-E4977. 


\section{$\&_{\mathrm{CSH}}^{\infty} \&$ Cold Spring Harbor

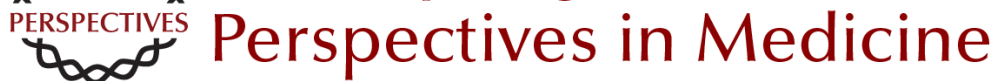

\section{Biology and Pathobiology of TDP-43 and Emergent Therapeutic Strategies}

Lin Guo and James Shorter

Cold Spring Harb Perspect Med 2017; doi: 10.1101/cshperspect.a024554 originally published online December 5, 2016

\section{Subject Collection Prion Diseases}

TDP-43 Prions

Takashi Nonaka and Masato Hasegawa

$\alpha$-Synuclein: Multiple System Atrophy Prions Amanda L. Woerman, Joel C. Watts, Atsushi Aoyagi, et al.

Genetics of Synucleinopathies Robert L. Nussbaum

$\beta$-Amyloid Prions and the Pathobiology of Alzheimer's Disease Joel C. Watts and Stanley B. Prusiner

Disease Mechanisms of C9ORF72 Repeat Expansions Tania F. Gendron and Leonard Petrucelli

Chronic Traumatic Encephalopathy: Is Latency in Symptom Onset Explained by Tau Propagation? Joshua Kriegel, Zachary Papadopoulos and Ann C. McKee

Noncerebral Amyloidoses: Aspects on Seeding, Cross-Seeding, and Transmission Gunilla T. Westermark, Marcus Fändrich, Katarzyna Lundmark, et al.

Structural and Chemical Biology of Presenilin Complexes

Douglas S. Johnson, Yue-Ming Li, Martin Pettersson, et al.
Cell Biology and Pathophysiology of $\alpha$-Synuclein Jacqueline Burré, Manu Sharma and Thomas C. Südhof

Molecular Mechanisms of Chronic Wasting

Disease Prion Propagation Julie A. Moreno and Glenn C. Telling

Genetics of Amyotrophic Lateral Sclerosis Mehdi Ghasemi and Robert H. Brown, Jr.

The Genetics of C9orf72 Expansions Ilse Gijselinck, Marc Cruts and Christine Van Broeckhoven

Prion-Like Characteristics of

Polyglutamine-Containing Proteins Margaret M.P. Pearce and Ron R. Kopito

Therapeutic Strategies for Restoring Tau Homeostasis

Zapporah T. Young, Sue Ann Mok and Jason E. Gestwicki

Fused in Sarcoma Neuropathology in Neurodegenerative Disease Ian R.A. Mackenzie and Manuela Neumann

Experimental Models of Inherited PrP Prion Diseases Joel C. Watts and Stanley B. Prusiner

For additional articles in this collection, see http://perspectivesinmedicine.cshlp.org/cgi/collection/ 